\title{
Mendialogkan Alquran dengan Pembacanya: Studi Atas Living Qur'an di Periode Klasik dan Pertengahan
}

\author{
H. Zuhri \\ UIN Sunan Kalijaga Yogyakarta, Indonesia \\ zuhri01@yahoo.com
}

DOI: http://dx.doi.org/10.29240/alquds.v3i2.814

Submitted: 2019-04-12 | Revised: 2019-10-18| Accepted: 2019-10-30

\begin{abstract}
The discourse on the Qur'an, until now, is still dominated by the dimensions of the internality of the Qur'an rather than its external dimension. Such conditions create the gap between the Qur'an on one hand and the readers or users of the Qur'an on the other. With using some cases of creating external Quranic dialouging as the core of analysis, this paper will answer the question how to re-readsome classical ideas or concepts in Islamic teaching and studies, especially those relating to the Qur'an, which actually shows the development of discourse for the context of the externalities of the Qur'an in the form of vertical dialogue between readers of al-Quran and the Qur'an itself. Although the existing discourse is still stay in the theological nuances and human interaction with the God, but the discourse has the potential to be further developed to enrich the tradition of Qur'anic studies. At the same time, in the perspective of the classical living al-Qur'an, it shows that the dialogue of Qur'an in the context of its externality means to dialogue the Qur'an in the context of humanity. Although it can not be separated from the divine dimension, the Qur'an becomes more alive in society and its humanity in the form of dialoging Qur'an with its readers and humankind generally.
\end{abstract}

Keywords: Dialogue, Alquran, āmin, sujud tilāwah, taqrìriyah, Living Qur'an, Yāsīn Fadīlah

Abstrak: Wacana tentang Alquran, hingga saat ini, masih didominasi oleh dimensi internalitas Alquran daripada dimensi eksternalnya. Kondisi seperti itu menciptakan kesenjangan antara Alquran di satu sisi dan pembaca atau pengguna Alquran di sisi lain. Dengan menggunakan beberapa kasus dialog eksternal Quran sebagai inti dari analisis, artikel ini akan menjawab pertanyaan bagaimana membaca kembali beberapa ide atau konsep klasik dalam pengajaran dan studi Islam, terutama yang berkaitan dengan Alquran, yang sebenarnya menunjukkan perkembangan wacana untuk konteks eksternalitas Alquran dalam bentuk dialog vertikal antara pembaca dan Alquran itu sendiri. Meskipun wacana yang ada masih tetap bernuansa teologis dan interaksi manusia dengan Tuhan, namun wacana tersebut memiliki potensi untuk dikembangkan lebih lanjut untuk memperkaya tradisi kajian Alquran. Pada saat yang sama, dalam 
perspektif Living Quran Klasik, menunjukkan bahwa dialog Alquran dalam konteks eksternalitasnya berarti dialog Alquran dalam konteks kemanusiaan. Meskipun tidak dapat dipisahkan dari dimensi Ilahi, Alquran menjadi lebih hidup dalam masyarakat dan kemanusiaannya dalam bentuk dialog Alquran dengan para pembaca dan umat manusia pada umumnya.

Keywords: Dialog, Alquran, āmīn, sujud tilāwah, taqrìriyah, Living Qur'an. dan Yāsīn Fadīlah

\section{Pendahuluan}

Alquran menjadi sumber rujukan bagi seluruh aspek dalam kehidupan umat Islam. Dari urusan-urusan Ibadah, Mu'amalah, itiqad, dan bahkan hal-hal yang terkait dengan hal-hal yang bersifat mistik sekalipun, Alquran selalu memberi jawaban dan perspektifnya. Perspektif yang ditawarkan oleh Alquran tersebut bukan berarti tanpa peran serta atau campur tangan manusia, semuanya berkaitan dengan posisi manusia atau ahli tafisr sebagai penafsir Alquran. Namun demikian, pada saat yang sama, manusia sebagai penafsir juga ditentukan atau dibatasi, dan diberi rambu-rambu yang ada di dalam Alquran itu sendiri. Semua itu berjalan secara dialektik dalam sejarah panjang keberadaan Alquran di tengah-tengah umat manusia pada umumnya dan umat Islam pada khususnya.

Pada umumnya, pemahaman Alquran difokuskan pada dua paradigma utama, pertama paradigma internalitas Alquran. Artinya, paradigma pemahaman tentang Alquran yang difokuskan pada dimensi teks, latar historis dan makna yang ada dalam lingkup internal Alquran. Bahwa Alquran menafsirkan dirinya sendiri (Alquran yufassiru ba'dhubu ba'dhan) menunjukkan karakteristik utama dari paradigm tersebut. Hampir semua pemikiran tafsr klasik dan modern yang berkembang di kalangan intelektual Muslim semuanya berkiblat pada kepentingan dimensi internalitas Alquran dalam arti eksplorasi bahasa, maknamakna, serta ajaran-ajaran yang terkandung di dalam Alquran. Kedua, paradgma yang difokuskan pada dimensi eksternalitas Alquran. Artinya, paradigma pemahaman tentang Alquran yang difokuskan pada dimensi di luar eksistensi Alquran namun masih memiliki keterkaitan dengan Alquran baik itu bahasa, sejarah, masyarakat, dan bahkan penafasiran atau pemahaman terhadap Alquran itu sendiri. Pada umumnya, paradigma ini dikembangkan oleh para Orientalis yang memfokuskan kajiannya pada Alquran sebagai teks kesejarahan.Mereka memahami dimensi historisitas Alquran yang lepas dari dimensi teologisnya. ${ }^{1}$

${ }^{1}$ Dua paradigm di atas yakni internalitas dan eksternalitas al-Qur'an, sampai penulisan makalah ini selesai, mungkin karena berbagai keterbatasan, penulis belum menemukan padanan konsep dan pijakan yang betul-betul bernas. Namun demikian, gagasan Angelika Neuwirth dalam “ Qur'an and History: A Disputed Relationship Some reflection on Qur'anic History and History in the Qur'an" yang dimuat dalam Qur'anic Studies, vol. 5, no. 1 (2003), hlm. 1-18 
Lepas dari kedua paradigma di atas, meskipun masih ada kaitannya dengan dua paradigma tersebut, ada fenomena menarik dari Alquran yang telah lama terjadi di kalangan umat Islam yakni konsep dialog dalam Alquran dan mendialogkan Alquran atau berdialog dengan Alquran. Keduanya tentu merupakan dua hal yang berbeda. Proses mendialogkan Alquran menunjukkan bahwa Alquran sebagai teks adalah sesuatu yang mandiri, pihak pendengar bacaaan Alquran juga sesuatu yang mandiri dan bahkan, pembaca Alquran itu sendiri juga merupakan sesuatu yang lain lagi. dengan demikian ada tiga pihak dalam proses dialog dengan Alquran. Yakni teks, pembaca dan pendengar bacaan Alquran. Baik pembaca maupun pendengar Alquran merupakan pihak yang berbeda sama sekali dengan teks Alquran, mereka berada di luar eksistensi Alquran. Artinya, keduanya ada ada dimensi eksternalitas Alquran sementara pada dimensi teks Alquran jelas menunjukkan dimensi internalitas Alquran. Dalam konteks ini telah terjadi dialog antara dimensi eksternalitas Alquran yang diwakili oleh pembaca atau pendengar di satu sisi dan dimensi internalitas Alquran yang diwakili oleh teks Alquran itu sendiri. Contoh yang sangat klasik dari dari proses yang disebut dialog semacam ini adalah pembacaan kata "āmīn" yang dilakukan oleh pembaca selesai membaca surat al-Fatihah secara lengkap ataupun pendengar selesai mendengarkan bacaan surat al-fatihah. Selain di kasus bacaan "āmīn", juga ada respon dalam bentuk dialog dalam bentuk jawaban, seperti bacaan "āmīn" tersebut, yakni tindakan dalam bentuk sujud tilawah, danmasih banyak bentuk respon pembaca lainnya. Salah satu bentuk dialog atau respon yang cukup menarik adalah fenomena Yasin Fadilah. Semua itu menunjukkan adanya dialog yang hidup (living dialogue) yang terjadi antara dimensi internalitas Alquran di satu sisi dengan eksternalitas Alquran, di sisi lain.

Alquran terhimpun dalam 30 juz, 114 surat, dan 6666 ayat. Kesemuanya terangkai dan teruntai dalam karakteristiknya yang khas dan penuh dengan keajaiban. Telah banyak ulama, intelektual, dan bahkan orientalis sekalipun yang telah menunjukkan keistimewaan dan keajaiban Alquran baik dari sisi struktur, huruf, kata, kalimat ataupun makna-maknanya. Upaya-upaya eksplorasi makna-makna Alquran menunjukkan kebenaran dan outentitas Alquran serta upaya mengeksplorasi makna-makna Alquran. Kandungan maknamakna Alquran dieksplorasi sedemikian rupa dalam ribuan kitab-kitab tafsir dan kitab-kitab hikmah sesuai dengan sudut pandang atau perspektif dan tujuan masing-masing. Semua sudut pandang dan tujuan eksplorasi disuuguhkan untuk menunjukkan keagungan Alquran.

merupakan bagian dari pergulatan dua paradgama di atas yang disebut oleh Angelika sebagai holism vs atomism atau revisionism versus tradisionalism. 
Perspektif yang dominan dalam memahami makna-makna Alquran adalah perspektif syari'ah. Artinya, pemahaman Alquran harus selalu identik dengan misi dan perspektif syari'ah sebagaimana yang dajarkan oleh Nabi Muhammad SAW. Perspektf ini biasanya mengedepankan tafsir bi al-ma'tsur, sebuah penasfiran Alquran yang berpegang teguh pada prinsip-prinsip penafsiran sebagaimana telah dijelaskan baik dari dalam Alquran itu sendiri maupun dari pemahaman yang disampaikan oleh Nabi Muhammad dan para sahabatnya. Namun demikian, sesuai dengan fakta-fakta historis yang ada, tidak sedikit ulama tafsir yang menafsirkan Alquran dengan menggunakan perspektif lainnya seperti perspektif kebahasaannya (lughawr) sebagaimana ditulis oleh alZamakhsyari ${ }^{2}$, hikmah-hikmah di balik makna-makna harfiah yang sering disebut sebagai tafsir isyari atau bathini sebagaimana ditulis oleh al-Alusi ${ }^{3}$, atau perspektif yang lebih kontemporer seperti tematik (maudhu') sebagaimana ditulis oleh Binti Syathi ${ }^{4}$. Perspektif klasik dan perspektif kontemporer tafsir masih menunjukkan karakteristik umum bahwa pemahaman-pemahaman Alquran cenderung instruktif yang datang dari dimensi internal Alquran sebagai representasi sabda-sabda Tuhan yang harus dipatuhi oleh manusia. Hal berbeda justru lahir dari proses dialog baik yang diprentasikan oleh Alquran itu sendiri maupun yang dirumuskan oleh intelektual Muslim dalam lintasan sejarahnya.

Ada nuansa kebebasan dan harapan-harapan yang diupayakan dan direflesikan oleh proses pendialogan Alquran, khususnya dalam konteks eksternalitas Alquran. Nuansa-nuansa itu sesungguhnya sangat dinamis dan hidup dalam ucapan-ucapan verbal, tindakan-tindakan tubuh, dan bahkan harapan-harapan yang ditulis dalam suatu doa dimana semuanya berangkat dari bagaimana pemahaman-pemahaman dari Alquran dijawab dan direspon oleh pembacanya. Oleh karena itu, tulisan ini bermaksud mensistematisasi fakta-fakta historis yang dapat dikategorikan sebagai suatu living Qur'an di era klasik, yakni era kenabian atau abad ke-7 sampai abad ke 13 M. Fakta-fakta tersebut kemudian dapat digeneralisasi bahawa pada era klasik konsep living Qur'an masih berkutat pada persoalan-persoalan ketuhanan atau teologis semata dan belum menyentuh pada persoalan kemanusiaan. Itulah fakta historis dan sekaligus tantangan studi living Qur'an kontemporer sekarang ini.

${ }^{2}$ Abū al-Qāsim Mahmud Umar al-Zamakhsyarī, al-Kassyāf an Haqāiq al-Tanžll wa Uyūn al-Ta'wül, (Bairut: Dar al-Ma'rifah, 2009).

${ }^{3}$ Syihūb al-Dīn Mahmud al-Alūsi, Rūh al-Ma'ānì fì Tafsìr al-Qur'àn al-'Adhìm, (Bairut: Dar Ihya al-Turats, 1981).

${ }^{4}$ Āisyah Abd al-Rahmān, al-Tafsìr al-Bayān li al-Qur'ān al-Karim, (Bairut: Dar al-Ma'arif. 1981). 


\section{Dialog dalam Alquran}

Kata dialog dalam bahasa Arab disebut dengan al-khiwār (الحوار) bentuk masdar dari khāwara (حاور) yang secara kharfiah berarti pembicaraan yang dilakukan oleh dua orang atau lebih. Pembicaraan yang demikian dalam bahasa Indonesia diistilahkan dengan dialog. Dalam Kamus Besar Bahasa Indonesia (KBBI) dijelaskan bahwa yang dimaksud dengan dialog adalah percakapan. KBBI juga menjelaskan bahwa percakapan yang dilakukan oleh dua pihak yang setara disebut dengan dialog horizontal, sedangkan dialog yang dilakukan oleh dua pihak yang tidak setara disebut dengan dialog vertikal. ${ }^{5}$ Kata dialog sendiri berasal dari bahasa Inggris Dialogue. Kata dialogue ini dari bahasa Yunanidialogos yang berasal dari kata dia (across) dan legein (to speak). Dialogueberarti usaha untuk berbagi tentang suatu makna atau hal dengan orang lain. Oleh karena itu, dialog selalu mengidealkan kesetaraan (equality), respek (empathy), komunikatif, dan terbuka (open minded). Menurut Mustansir Mir, yang dimaksud dengan dialog dalam Alquran adalah; a significant verbal exchange that takes place between two or more parties in a given situation". 6

Di dalam Alquran, konsep al-khiwär merupakan salah satu pola bahasa atau style tuturan kalimat atau kebahasaan yang ada di dalam Alquran. Dalam konteks ulum Alquran, konsep al-khiwār merupakan salah satu dari uslub yang ada dalam Alquran. Uslub itu sendiri dipahami sebagai pilihan gaya bahasa yang digunakan oleh penutur bahasa, konsep ini sering juga diistilahkan dengan Stilistika. Oleh karena itu tidak sedikit kata-kata atau tepatnya kalimat-kalimat di dalam Alquran yang menggunakan pola al-kbiwāar atau dialog. Pola ini biasanya terjadi dalam bentuk tanya jawab atau perbincangan yang dilakukan oleh dua pihak atau lebih. Di dalam Alquran sendiri menurut Dhamrah terdapat, minimal tiga ayat yang menjelaskan tentang kata al-khiwarryakni terdapat QS. al-Kahfi: 34, dan 37, dan QS. al-Mujadalah: 1. Sementara pola al-khiwär juga banyak ditemukan di dalam Alquran seperti tentang perbincangan atau dialog antara Nabi Musa AS. dengan Khidir AS (QS. al-Kahfi, 65), dialog nabi Adam dengan Tuhannya (QS. al-Baqarah: 31) dan masih banyak contoh lainnya. Dialog-dialog tersebut menunjukkanadanya proses komunikasi di antara dua pihak. ${ }^{7}$ Gambaran di atas menguatkan pendapat yang menyatakan bahwa uslub al-kbiwar pada umumnya muncul pada ayat-ayat al-qissah di dalam Alquran.

${ }^{5}$ Kementerian Pendidikan dan Kebudayaan RI, Kamus Besar Bahasa Indonesia, (Jakarta : Balai Pustaka, 2001), hlm.

${ }^{6}$ Mustansir Mir, "Dialogue in the Qur'an", Religion and Language. Vol. 24, No. 1, 91992), hlm. 3.

${ }^{7} \mathrm{Ma}$ 'en Mahmoud Otsman Damrah, al-Khiwar fi al-Qur'an al-Karim, (Nablus: al-Jami'ah al-Najakh al-Wathaniyyah, 2005 ) hlm. 21-26. 
Mahmoud Damrah lebih jauh menunjukkan bahwa konsep dialog dalam internal Alquran tidak semata dalam konteks pola penuturan atau gaya tutur bahasa yang ada di dalam Alquran tetapi juga kaidan dan konsep dialogitu sendiri berikut berbagai varian yang ada di dalamnya yang, menurut Otsman Damrah, juga terdapat di dalam Alquran. ${ }^{8}$ Menurutnya, Alquran telah menyediakan konsep sekaligus arti penting khiwar al-khadarah atau dialog kebudayaan dan peradaban bagi umat manusia. ${ }^{9}$ Berangkat dari realitas antropologis manusia yang tercipta dalam berbagai suku, bangsa, warna kulit, budaya dan bahkan agama, Alquran menggarisbawahi pentingnya sharing, berkumunikasi untuk saling mengetahui dan memahami. Hal itu juga sebagaimana yang termaktub dalam QS.49 (al-Hujurat); 13.

Sementara Sayyid Mohammad Husain Fadhlullah lebih jauh menegaskan bahwa Alquran pada dasarnya merupakan kitab dialog (kitab alkbiwar). Penekanan ini perlu digarisbawahi oleh Fadlullah karena memang baik dari sisi konten, uslub, sejarah, maupun dinamika yang ada di dalam Alquran tidak lepas dari proses dan prinsip-prinsip dialogis. ${ }^{10}$ Namun demikian bukan berarti Alquran dalam posisi tertekan. Deskripsi dialog-dialog yang berujung pada perdebatan sekaligus menunjukkan bahwa melalui proses dialog Alquran berhasil menyentuh pola nalar yang paling dalam tentang sebuah kebenaran, agama, dan nilai-nilai moral melalui kisah para rasul, dan gambaran orang-orang yang berfikir sesat. Melalui dialog, Alquran menjernihkan konsep-konsep aqidah atau keimanan yang tercemari oleh prilaku-prilaku sejarah yang dengan sengaja atau tidak mencoba mengaburkan konsep tauhid yang diusunng oleh Alquran. ${ }^{11}$

Pandangan lain ditunjukkan oleh Mustansir Mir, dengan mengutip pandangan Richard Bell, salah seorang intelektual Barat yang menerjemahkan Alquran ke dalam bahasa Inggris, Montgomery Watt, Rudi Paret, dan bahkan menurut Sayyid Qutb sendiri dalam al-Tashwir fi Fanni Alquran, menurutnya gagasan tentang konsep dialog di dalam Alquran belum banyak dieksplorasi oleh intelektual modern. Pandangan Mustansir ini tentunya kerena ketidaktahuannya atas referensi-referensi di kalangan internal Islam tentang studi Alquran. Padahal jika konsep dialog di atas dibaca dalam konteks uslub Alquran berarti konsep tersebut telah ada jauh sebelum lahirnya studi-studi Qur'an modern sekarang ini. Lepas dari asumsi tersebut, Mustansir berpendapat bahwa dialog dalam Alquran sebagai bagian dari literary feature of the Qur'anyang memiliki tipologi, struktur, karakter dan urgensi yang meneguhkan eksistensi Alquran sebagai kitab suci

${ }^{8}$ Ibid., hlm. 119-130.

Ibid., hlm. 183-190.

${ }^{10}$ Sayyid Mohammad Husain Fadhlullah, al-Kbiwar fi al-Qur'an : Qawa'iduhu, Asalibubu, wa Mu'tiyatubu (Bairut: Dar al-Malak, 2007), hlm. 43-44.

${ }^{11}$ Ibid. 
umat Islam. Salah satu urgensi dialog adalah untuk membedakan pola literature Jahili yang cenderug monoton. ${ }^{12}$

Meskipun dalam konteks pembacaan pendidikan, konsep dialog Alquran yang diusung Mahmud Arif cukup menarik. Menurutnya, aspek dialogis Alquran adalah pola pewahyuan Alquran yang bertahap karena aspek progresivitas dan refleksi-interaksi kreatif antara dimensi Ketuhanan, realitas empiris, dan kebutuhan masyarakat. ${ }^{13}$ Fakta historis yang demikian itu hendaknya menjadi inspirasi bagi pemahaman dan pengembangan pendidikan dalam Islam. Lepas dari konteks tersebut, satu hal yang perlu digarisbawahi bahwa konsep dialog Alquran sebagai bentuk dialog (baca: komunikasi) proses pewahyuan firmanfirman Allah kepada utusan-Nya yakni nabi Muhammad saw. Untuk masyarakat sekitar dan umat manusia pada umumnya.

Gagasan-gagasan tentang dialog dalam Alquran yang ada selama ini masih terfokus pada studi tentang fakta dan konsep dialog yang ada dalam teks Alquran (dialogue in the Qur'an). Inilah yang dimakud dengan konsep dialog dalam ranah internal Alquran. Orientasi dan visinya jelas, yakniingin menunjukkan prinsip dan nilai-nilai keagamaan dan ajaran-ajaran keislaman yang diusung oleh Alquran melalui uslub dialog atau bahkan tentang konsep pentingnya dialog. Semua kajian di atas masih dalam kerangka studi Alquran atau ulum Alquran, dalam terminologi klasik. Alquran masih dipahami dalam potongan-potongan ide-ide objektifnya dan dalam kerangka penalaran dan rasonalitas yang terukur sesuai dengan mainstream pemikiran keagamaan yang ada selama ini. ${ }^{14}$

Pada saat yang sama, melalui ide-ide kreatif sejarah, Alquran berdialog, didialoggkan, dan mendialogkan dirinya dengan dan dalam kehidupan (dialogue with the Qur'an). Dialog dalam hal ini tentu maknanya tidak sebagaimana pemahaman di atas yang difokuskan pada dimensi internalitas Alquran. Kerangka kerja proses mendialogkan Alquran yang demikian ini sebenarnya merupakan bagian dari proses tumbuh kembangnya Alquran dalam realitas kehidupan, atau dalam terminlogi kontemporer sering disebut dengan Living

${ }^{12}$ Mustansir Mir, "Dialogue in the Qur'an”. hlm. 19.

${ }^{13}$ Mahmud Arif, “Aspek Dialogis al-Qur'an dalam Pendidikan: Arti Penting Pembacaan Pedagogis dan Produktif”, dalam Jurnal al-Tabrir, Vol. 11, No. 2 (2011), hlm. 298.

${ }^{14}$ Mengikuti periodesasi sejarah studi al-Qur'an memang masih dalam perdebatan, ada pandangan yang memilih studi al- Qur'an dalam dua periode yakni klasik dan modern. Adapula pandangan yang memilah ke dalam tiga periode yakni klasik, pertengahan dan modern. Beberapa kasus pewacanaan dan tindakan kolektif yang terhubung dalam al-Qur'an dalam tulisan ini bisa dipastikan tidak terbatas pada era klasik namun juga kasus yang muncul pada era pertengahan. Jelasnya, ada perbedaan sudut pandang bagaimana intelektual di bidang studi Qur'an dan Tafsir berbicara tentang periodesasi kesejarahan studi al-Qur'an. 
Qur'an. ${ }^{15}$ Oleh karenanya, gagasan living Qur'an sebaiknya harus didahului dengan lahirnya dialog dengan Alquran atau mendialogkan Alquran. Tanpa ada tradisi dialog dengan Alquran usaha membangun living Qur'an akan sia-sia.

Tradisi mendiaogkan Alquran ini dalam konteks klasik maupun kontemporer sekarang ini belum banyak dieksplorasi lebih jauh. Padahal, aktivitas mendialogkan Alquran telah terjadi jauh bahkan pada saat Alquran diturunkan kepada Nabi Muhammad saw. Pada saat itulah sebenarnya Alquran menjadi sebuah entitas yang hidup karena selalu dikelola olah nalar keagamaan yang terus tumbuh dalam lintasan ruang dan waktu. Proses kesejarahan mendialogkan Alquran, meskipun pada awalnya lebih terbuka, independen dan dinamis, namun oleh karena hegemoni pemikiran fiqh yang semakin menguat maka hampir seluruh proses kesejarahan di atas ditafsirkan dalam konteks fiqh atau syariah dalam arti yang lebih umum. Rekaman sejarah tentang tradisi mendialogkan Alquran kemudian terdistorsi dalam diskursus fiqh yang terbatas pada rasionalitas halal-haram, sah-tidak sah, dan baik-tidak baik.

Ada beberapa contoh bagiamana mendialogkan Alquran era klasik yang jelas menunjukkan living Qur'an dan dalam bingkai yang tidak semata dalam konteks internal tetapi justru dengan dimensi eksternal Alquran baik dalam bentuk kebahasaan maupun tindakan yang kemudian menjadi keterpaduan yang indah. Di antara ruang-ruang dialog tersebut terdapat dalam konsep "amin", sujud tilawah, kaliat-kalimat Iqräryizah, dan Yasin Fadilah.

Dari eksplorasi gagasan tentang dialog dalam Alquran di atas, tulisan ini merumuskan bahwa yang dimaksud dengan dialog Alquran atau mendialogkan Alquran bukan pada konsep dialog yang ada di dalam Alquran, tetapi pada konsep bagaimana pembaca dan pendengar (bacaan) Alquran mendialogkan dirinya secara individu maupun kolektif baik dengan ucapan, tindakan, atau harapan. Oleh karena itu mendialogkkan Alquran berarti melakukan proses eksternalisasi Alquran dengan pembacanya sehingga nilai-nilai Alquran dapat terinternalisasi di dalam diri setiap pembacanya.

\section{Respon Verbal dengan jawaban $\bar{A} m \bar{m} n$}

Kata ämin tidak ditemukan di dalam Alquran. Di dalam Alquran hanya ada kata āmminn, meskipun berasal dari turunan yang sama yakni a-m-n, sebagaimana disebut dalam QS.al-Maidah: 2 dalam kalimat; àminnal bait al-barām,

\footnotetext{
${ }^{15}$ Penulis tentunya tidak menggunakan konsep living Qur'an dalam terminologi studi Qur'an kontemporer yang marak akhir-akhir ini sehingga penulis juga tidak terjebak dalam bingkai disiplin wacana tersebut. Istilah living qur'an di sini lebih dimaknai sebagai penanda adanya kreativitas qur'ani di kalangan masyarakat Muslim klasik, terutama kreativitas membangun konfigurasi dialogis yang kompleks antara bahasa al-Qur'an, tindakan kolektif dan sejarah.
} 
tetapi konteks dan maknanya berbeda dengan kataāmin. Kata ämin merupakan bentuk ism-fi'ilamr (kata benda yang menunjukkan arti tindakan atau printah) yang statis (mabni) sedangkan kata àmminnmerupakan isim fa'il yang diambil (musytaq) dari kata dasar à-ma-na, yang artinya memberi perlindungan, jadi àmminnadalah subjek (zat) Allah yang memberi perlindungan. Kata ämin ini paling sering disebut setelah membaca surat al-Fātihah. Secara umum, selama ini pandangan dan posisi tentang kata amin lebih pada persoalan apakah kata tersebut merupakan bagian dari Alquran atau tidak? Bagaimana hukum membaca amin? Tidak ada klausul penjelasan tentang bagaimana sesungguhnya konstruksi jawaban dengan kata äminsetelah membaca surat surat al-Fātihah. Artinya, selama ini kata ammin berikut penggunaanya lebih diorientasikan pada pemahaman instruktif dan bukan pemahaman dialogis. Padahal, pada awalnya konsep amin merupakan bagian dari simbol-simbol bahasa dialogis yang dimunculkan oleh penganut theistik, tidak terkecuali di dalamnya adalah umat Islam. ${ }^{16}$

Sejarah telah menunjukkan bahwa kata ämin merupakan jawaban konfirmatif yang disampaikan oleh orang-orang beragama baik itu Muslim, Nasrani, ataupun Yahudi tentang keesaan dan kemahakuasaan Allah. Oleh karena itu, kata ämin merupakan salah satu kosa kata klasik keagamaan. Kata ini terdapat dalam bahasa Suryani dan juga ditemukan dalam bahasa Ibrani serta tentu saja dalam bahasa Arab. Kata amin semuanya memiliki arti yang sama, yakni ikrar pengakuan konfirmatif yang dilakukan oleh orang orang yang beriman kepada Tuhan yang Esa (monotheistic) atau dalam bahasa Arab disebut dengan shadaqa wa tsabata bi al-imän. Oleh karena itu al-Thabari menekenankan kata ämminasebagai jawaban konfirmatif sebagai orang yang punya kehendak atau keinginan yang disertai dengan keyakinan ${ }^{17}$.

Pernyataan konfirmatif ini dideklarasikan oleh umat Islam setelah mendengarkan atau membaca tujuh ayat pertama dalam Alquran atau yang sering disebut sebagai surat al-fätibah. Pemahaman yang demikian sebenarnya sejalan dengan hadits nabi Muhammad sebagaimana diriwayatkan oleh Bukhari dan Muslim. ${ }^{18}$ Bahkan dalam tafsir Ibn Katsir juga dijelaskan secara gamblang

${ }^{16}$ Dalam Catholic Encyclopedia Dictionary misalnya ditulis ;"The word Amen was introduced or taken over from the usage the synagogue into publica and private prayer in opostolic times. Sometimes it merely marks the end of a prayer it is an expression of assent (as after the creed) or of agreement (as after petition). Ronald Attwater, The catholic Encyclopedia Dictionary, (London: Cassel Company, 1949), blm. 20..

${ }^{17} \mathrm{Ibn}$ Jarir al-Thabari, Tafsir al-Thabari, juz 9, ( Bairut: t. tp. t.th), hlm. 471.

${ }^{18}$ Adapun sanad dan teks hadits dari Bukhari adalah sebagai berikut:

حدثنا عبد الله بن يوسف أخبرنا مالك عن سمي عن أبي صالح عن أبي هريرة أن رسول الله قال: إذا إلها

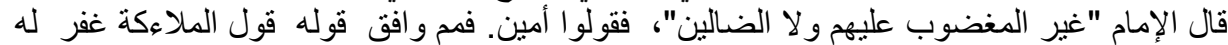
ما تقدم من دنبه. 
tentang anjuran membaca kata "āmīn" setelah menyelesaikan pembacaan surat al-fātihah, sebagaimana terdapat dalam table I.

\section{Tabel I}

Skema Dialog Pembaca Alquran dengan Teks a-Qur'an dalam QS. al-Fatihah Ayat ke-7

\begin{tabular}{|c|c|c|c|}
\hline 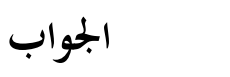 & النص & السورة & 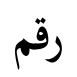 \\
\hline 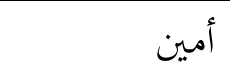 & غير المغضوب عليهم ولا الضالين & الفاتحة 7 & 1 \\
\hline
\end{tabular}

Persoalan pemahaman pembacaan kata "āmīn" dalam konteks mendialogkan Alquran seyogyanya berangkat dari latar pemikirian bahwa selama ini pemahaman atas hadits-hadits Nabi semenjak proses kodifikasi hadits sampai sekarang selalu terjebak dalam konteks hukum (figh), atau lebih tepatnya menutamakan dimensi-dimensi fiqhiyyah daripada dimensi-dimensi historisitas hadits. ${ }^{19}$ Padahal, tidak semua hadits harus dikembalikan kepada nalar fiqh. Oleh karena itu perlu upaya membangun kesadaran dan penalaran reflektif atas pentingnya ikrar atau pengakuan yang harus diucapkan oleh seseorang yang secara langsung maupun tidak langsung diminta untuk melakukan konfirmasi atas statemen-statmen awal dalam surat al-fatihah yang disampaikan baik oleh pembaca Alquran ataupun yang secara integral termaktub dalam pesan-pesan yang hadir dari surat al-fatihah sebagai firman Allah swt. Dengan latar di atas, jawaban ämin merupakan dimensi eksternal Alquran sedangkan latar yang melahirkan jawaban tersebut yakni pemahaman atau pembacaan atas tujuh ayat surat al-fātihah yang merupakan bagian atau dimensi internal Alquran. Hadirnya dimensi eksternal Alquran di tengah-tengah proses presentasi internalitas Alquran menunjukkan adanya pola bersahut-sahutan Alquran dengan bahasa atau dimensi di luar Alquran. Proses sabut menyahut inilah yang dapat diidentifikasi sebagai proses pendialogan Alquran.

Pola demikian merupakan bentuk pemahaman dialogis paling klasik yang dikembangkan dalam tradisi pembacaan Alquran. Dikatakan paling klasik karena pada waktu tafsir belum lahir namun pemahaman masyarakat terhadap Alquran mulai lahir dalam bentuk respon-respon positif terhadap diktum-diktum

Abi Abdillah Muhammad binIsmail al-Bukhari, Sabih al-Bukhari, jilid III, (Bairut: Dar al-Fikr, 1981), hlm. 146.

${ }^{19} \mathrm{Hal}$ itu bisa dibaca dalam pemahaman yang dibangun oleh al-Nawawi terhadap konsep ämin. Bagi al-Nawawi, hal yang ditekankan meliputi cara baca kata ämindan landasan argumennya, bukan pada makna dibalik keberadaan kata ämin dalam tradisi keagamaan Islam. Lihat, Yahya bin Syaraf al-Nawawi, al-Tibyan fi Adab Hamalat al-Qur'an, (Bairut: Dar al-Nafais, 1984), hlm. 87-88. 
keagamaan yang disampaikan melalui Alquran. Namun demikian, pemahaman dialogis seperti kasus kata ämindi atas tidak banyak ditemukan di dalam referensi sehingga sulit untuk membuktikan dokumen ataupun referensi yang menunjukkan hal tersebut. Persoalan lain apakah kemudian penafsiran atas konsep amin dalam konteks individu atau masyarakat yang mengikrarkannya sebagai bentuk kepatuhan ataupun ketidakberdayaan manusia di hadapannya Tuhannya? Jawabannya tentu membutuhkan kerangka analisis lainnya. Yang jelas, jawaban àmin atas pembacaan surat al-fätihah merupakan bagian dari proses pemahaman dialogis vertikal seorang hamba di hadapan Tuhannya.

\section{Respon Tindakan atas Pembacaan Ayat Alquran (Sujud Tilawah)}

Di antara konsep lain yang dekat dengan proses mendialogkan Alquran, khususnya dialog antara pembaca dan pendengar Alquran, adalah sujud altiläwah. Istilah sujud sendiri sebenarnya sudah menjadi tradisi dan ritual keagamaan Islam paling awal dan fundamental, khususnya dalam rangkaian ibadah shalat. Di luar shalat, ada tradisi sujud yang lain seperti sujud untuk ungkapan rasa syukur, dan sujud untuk konfirmasi setelah membaca ayat-ayat tertentu di dalam Alquran atau sering diistilahkan dengan sujūd al-tiläwah. Dengan demikian dapat disederhanakan bahwa yang dimaksud dengan sujud al-tilawah adalah respon tindakan bersujud yang disebabkan oleh adanya pembacaan (altilawah) Alquran. ${ }^{20}$ Sementara Ibn Taimiyah mengistilahkan sujüd al-tiläwah dengan sujüd Alquran. ${ }^{21}$ Dalam konteks tertentu, tindakan bersujud itu sendiri, di antara maknanya, merupakan bagian dari etika penghormatan dari yang muda kepada yang lebuh tua dan penghormatan rakyat kepada rajanya, atau penghormatan kepada pihak lain yang lebih mulia, sebagaimana dalam kasus Adam. ${ }^{22}$ Lebih jauh lagi, bahwa tradisi sujud sebenarnya menjadi bagian dari tradisi agamaagama samawi seperti Yahudi dan Kristen. ${ }^{23}$ dalam Alquran sering disebut dengan àyät al-sajdahatau dalam bahasa yang sederhana dipahami sebagai; ayatayat dalam Alquran yang menganjurkan para pembacanya untuk melakukan sujud. Atau dibalik, kesunnahan melakukan tindakan sujud setelah membaca ayat-ayat yang dikategorikan sebagai āyät al-sajdah. Tindakan ini dilakukan atas

${ }^{20}$ Salih bin Abdullah al-Laham, Sujūd al-Tilāwah wa Ahkämubu, (Riyadh: Dar Ibn alJauzi, 1429 H), hlm. 17.

${ }^{21}$ Taqi al-Din Ahmad Ibn Taimiyyah, Sujūd al-Tilāwab: Ma'ànīhi wa Abkämibi, (Bairut: Dar Ibn Hazm, 2011).

${ }^{22}$ QS. 2: 30-33.

${ }^{23}$ Roberto Tottoli, "Muslim Attitudes Toward Prostration (Sujūd) I: Arabs and Prostrations at the Beginning of Islam and in Qur'an", dalam Studia Islamica, No. 88 (1998), hlm. 6 
dasar informasi terpercaya bahwa Nabi Muhammad SAW. melakukan sujud tilawah. Hal itu terdapat dalam hadits sebagaimana diriwayatkan oleh $\mathrm{Nafi}^{24}$ dan Abu Hurairah ${ }^{25}$.

Tentang jumalah ayat yang terdapat anjuran untuk bersujud, al-Syafi'i menulis bahwa jumlah ayat al-sajdah ada empat belas ${ }^{26}$ Sementara para ulama ulama yang lain menghitung ada limabelas ayat yang disarankan untuk melakukan sujud tilawah. ${ }^{27}$ Kelimabelas ayat tersebut adalah sebagai sebagaimana dalam table I.

Tabel II

Ayat-ayat yang Mendapat Respon Tindakan (Sujud Tilawah)

\begin{tabular}{|c|c|c|}
\hline 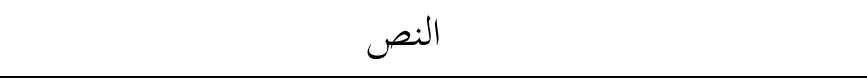 & 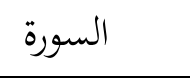 & رقم \\
\hline إن الذين عند ربك لا يستكبرون عن عبادته ويسبحونه وله & & 1 \\
\hline يسجدون & 206 & \\
\hline ولله يسجد من في السماوات والأرض طوعاً وكرها وظلالهم & 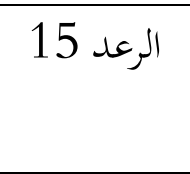 & 2 \\
\hline وهم لله يسجد ما في السماوات وما في الأرض من دابة والملائكة & النحل 49 & 3 \\
\hline قل آمنوا به أو لا تؤمنوا إن الذين أوتوا العلم من قبله إذا يتلى & 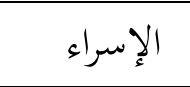 & 4 \\
\hline
\end{tabular}

${ }^{24}$ Hadits riwayat Nafi ini terdapat dalam Sahih Muslim, di bab kitab al-masajid wa mawadhi al-sujud, Teks lengkap hadits tersebut adalah sebagai berikut;

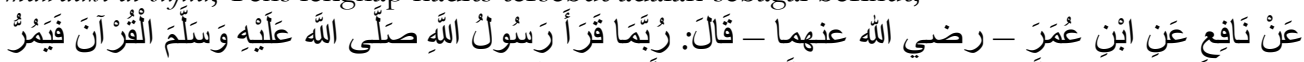

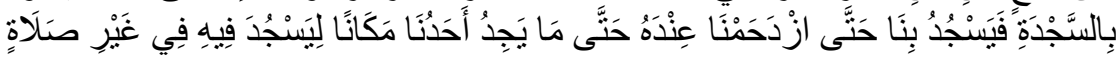

${ }^{25}$ Sementara hadits riwayat Abu Hurairah ini terdapat dalam Sahih Muslim di bab kitab al-iman, teks lengkap hadits tersebut adalah sebagai berikut;

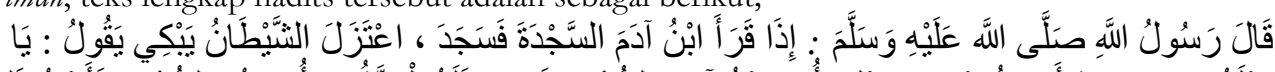

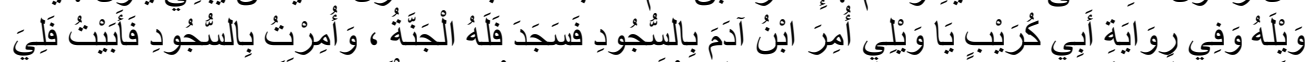

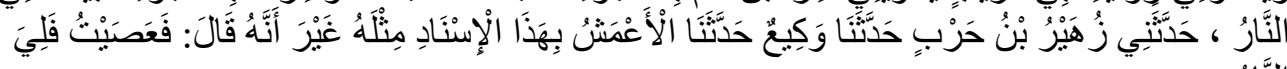

${ }^{26}$ Yahya bin Syaraf al-Nawawi, al-Tibyan fi Adab Hamalat al-Qur'an, hlm. 89.

${ }^{27}$ Dalam catatan Salih bin Abdullah dijelaskan bahwa dari 15 ayat tersebut ada 5 ayat yang masih berbeda di kalangan ulama madzhab. Namun secara umum dapat dipahami bahwa kelimabelas ayat tersebut berkait dengan sujud al-tilawah. Salih bin Abdullah, Sujüd al-Tiläwah wa Abkämubu, hlm. 47-72. 


\begin{tabular}{|c|c|c|}
\hline عليهم يخرون للأذقان سجداً & 107 & \\
\hline إذا تتلى عليهم آيات الرحمن خروا سجداً وبكياً & مريم & 5 \\
\hline ألم تر أن الله يسجد له من في السماوات ومن في الأرض & الحج 18 & 6 \\
\hline والشمس والقمر والنجوم والجبال والشجر والدواب وكثير حق & & \\
\hline عليه العذاب ، ومن يهن الله فما له من مكرم ، إن الله يفعل ما & & \\
\hline يشاء & & \\
\hline يأيّهَا الذين آمنوا اركعوا واسجدوا واعبدوا ربكم وافعلوا الخير & الحج & 7 \\
\hline ل لعلكم تفلحون & & \\
\hline وإذا قيل لمم اسجدوا للرحمن قالوا وما الرحمن أنسجد لما تأمرنا ، & 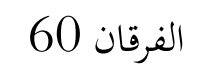 & 8 \\
\hline وزادهم نفورا & & \\
\hline إلا يسجدوا لله الذي يخرج الخنبء في السماوات والأرض ويعلم & النمل 25 & 9 \\
\hline ما تخفون وما تعلنون & & \\
\hline إنما يؤمن بآياتنا الذين إذا ذكروا بها خُرُوا سجداً وسبحوا بحمد & السجدة & 10 \\
\hline ربكم وهم لا يستكبرون & & \\
\hline وظنَّ داود أنما فتناه ، فاستغفر ربه وخرَّ راكعاً وأناب & ص ص n n & 11 \\
\hline ومن آياته الليل والنهار والشمس والقمر لا تسجدوا للشمس ولا & فصلت & 12 \\
\hline للقمر واسجدوا لله الذي خلقهن إن كنتم إياه تعبدون & & \\
\hline فاسجدوا لله واعبدوا & النجم & 13 \\
\hline وإذا قُرئ عليهم القرآن لا يسجدون & الإنشقاق & 14 \\
\hline & 21 & \\
\hline 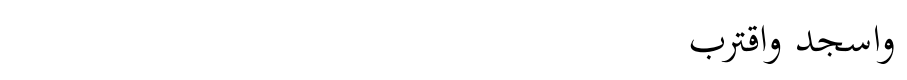 & العلق 19 & 15 \\
\hline
\end{tabular}

Secara umum, 15 ayat di atas menunjukkan tentang konsep dan perintah untuk melakukan tindakan sujud. Baik konsep maupun tindakan, respon 
pembaca adalah dengan melakukan tindakan sujud. Dengan demikian substansinya sujud al-tilawah meruipakan respon pembaca atas makna atau pemahaman yang terkandung dalam ayat tersebut. Secara sekilas, tindakan sujuddi atas dipahami sebagai suatu respon semata. Namun jika ditelusuri lebih dalam ada komunikasi intensif meski tidak langsung antara pembaca Alquran di satu pihak dengan Allah sebagai Khatib Alquran dipihak lain. pada saat yang sama, pembaca Alquran yang melakukan sujud juga menyampaikan pandangan dan harapannya melalui konsep doa. ${ }^{28} \mathrm{Di}$ antara pandangan dan doa tersebut adalah sebagai berikut;

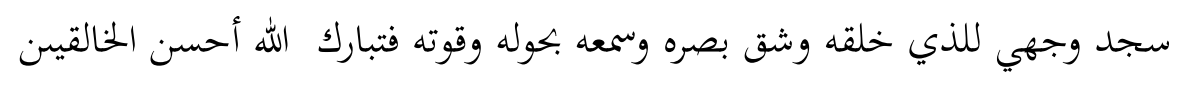

Selain bacaan di atas, di dalam hadits ada bacaan lainnya yang dapat dijadikan alternative pembacaan. Namun demikian, substansinya tetap pada adanya proses dialog dan komunikasi bagi pembaca Alquran dengan Allah swt. Proses komunikasi ini yang perlu digarisbawahi sebagai bentuk kepatuhan ataupun usaha untuk membangun kesadaran dan menaklukan raga dan jiwa dalam sebuah keyakinan. Proses ini tidak dapat dipahami secara maksimal jika seorang pembaca tidak mengerti betul makna dalam ayat-ayat tersebut. ${ }^{29}$ Oleh karena itu, apa yang terjadi sekarang ini, sujud tilawah menjadi bagian dari proses dialog simbolik yang ada dalam konteks Alquran sebagai sebuah media yang sedang didialogkan dengan pembacanya.

\section{Respon Verbal atas Pembacaan Ayat Alquran}

Yang dimaksud dengan respon atas ayat di sini adalah suatu jawaban konfirmatif atau responsifatas statemen dan pertanyaan-pertanyaan yang disuguhkan dalam Alquran. Ada banyak ayat yang menggunakan uslub statemen-stateen tertentu dan pertanyaan yang tidak ada jawaban di dalam Alquran. Atas realitas ini, muncul jawaban-jawaban konfirmatif yang dilakukan oleh para sahabat Nabi pada waktu. Tradisi awal dari para sahabat itu kemudian disistematsasi oleh al-Ghazali. Menurutnya, di tengah-tengah membaca Alquran, ketika seseorang melewati suatu ayat yang berisi mensucikan Allah, dia bertasbih dan bertakbir, ketika melewati ayat yang berisi permohonan dan minta ampunan, dia berdo'a dan beristighfar, ketika melewati ayat yang berisi harapan dia

\footnotetext{
${ }^{28} \mathrm{Hal}$ inilah yang kemudian di dalam konteks hadits, sebagaimana diriwayatkan oleh Imam Muslim, yakni; أقرب ما بكون العبد من ربه وهو ساجد فأكثروا الدعاء. bagian sebagian orang doa mungkin secara sederhana dimaknai sebagai permintaan. Namun, substansinya doa merupakan dialog intensif antara manusia dengan Tuhannya.

${ }^{29}$ Oleh karena itu, tidak aneh rasanya jika Ibn Taimiyyah menggarisbawahi bahwa di dalam konsep sujud al-tilawah satu hal yang perlu diperhatikan adalah pentingnya pemahaman dan kepatuhan (ibadah) terhadap ayat-ayat Allah. Hal ini lah yang menjadi dasar dan filosofi bagi konsep sujud al-tilawah.Ibn Taimiyyah, Sujūd al-Tilāwah: Ma'änībi wa Abkämibi, hlm. 36.
} 
mengajukan permohonan dan ketika melewati ayat yang berisi hal-hal yang menakutkan, dia memohon perlindungan. Itu semua dia lakukan dengan ucapan lisannya atau digerakkan dalam hatinya. ${ }^{30}$ Oleh karena ituMasih dalam konteks yang sama, logika yang dibangun al-Nawawi (w. 676 H.) adalah bahwa pembaca disunnahkan untuk merespon ayat-ayat tertentu, seperti ayat-ayat dalam Alquran yang mengandung rahmat untuk meminta rahmat dan pengampunan, sementara dalam membaca ayat-ayat yang mengandung azab maka dianjurkan untuk membaca isti'adah (perlindungan) atau tasbih. ${ }^{31}$ Sebagai suatu kasus, ayatterakhir dari surat al-Tin bisa dijadikan sebagai contoh. Dalam konteks ini, tafsir alThabari mendeskripsikan permasalahan di atas sebagai berikut; ${ }^{32}$

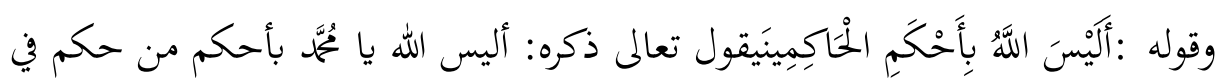

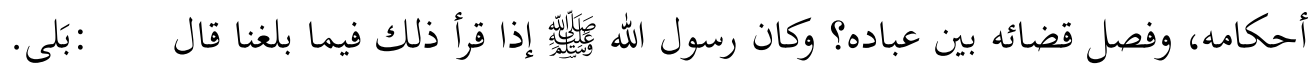

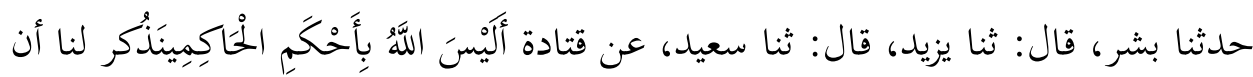
نبيّ الله

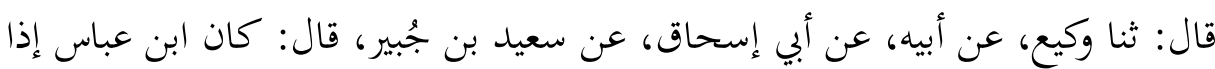

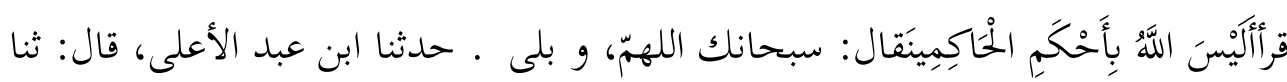

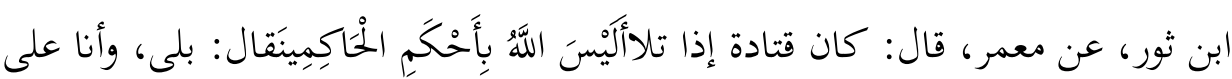

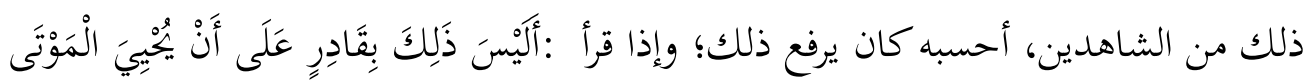

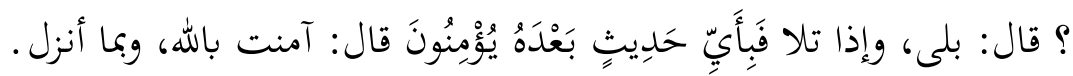

Pandangan al-Thabari di atas dan beberapa eksplorasi yang penulis temukan, pola-pola jawaban atas kalimat-kalimat tanya dalam Alquran sebagaimana dalam tabel III berikut ini.

279.

${ }^{30}$ Abū Hāmid al-Ghazālī, Ikkhyà Ulüm al-Dìn, (Bairut: Dar al-Fikr, t. th.), juz I, hlm.

${ }^{31}$ Lebih jelas al-Nawawi menulis;

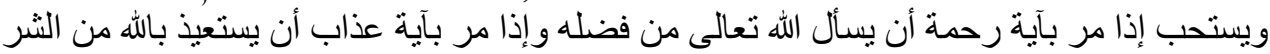

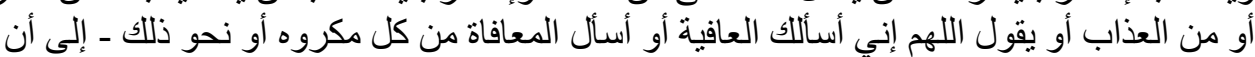

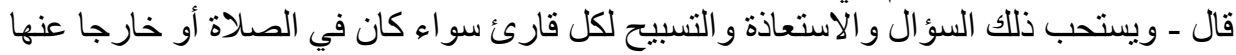

Yahya bin Syaraf al-Nawawi, al-Tibyàn fi Adāb Hamalat al-Qur'an, hlm . 90.

${ }^{32} \mathrm{Abū}$ Ja'far Muhammad bin Jarīr al-Thabārī, Jämi al-Bayān fiTafsìr al-Qur'ān, juz 2830, (Bairut: Dar al-Ma'rifat, 1972), hlm. 160-161. 
Tabel III

Ayat-Ayat Alquran yang diberi Respon Verbal secara Langsung oleh Pembacanya

\begin{tabular}{|c|c|c|c|}
\hline الجواب & النص & السورة & رقم \\
\hline لا إله الا أله & أَإِلَهُه مَعَ اللَّهِ & النحل 80 & 1 \\
\hline \multirow{2}{*}{ فبلى وأنا على ذلك من } & 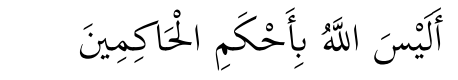 & التين & 2 \\
\hline & & & \\
\hline 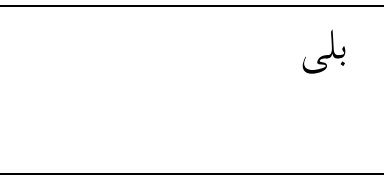 & أَلْيْنَ ذَلِكَ بِقَادِرٍ عَلَى أَنْ يُجِيْيَ & النحل 49 & 3 \\
\hline أمنت بالله وبما أنزل & فَبَأَيّ حَدِيثٍ بَعْدَهُ يُؤْْمنُونَ & المرسلات 50 & 4 \\
\hline 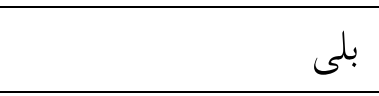 & أَلْْسَ اللَّهُ بِكَافٍ عَبْدَهُ & 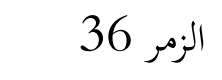 & 5 \\
\hline بلى & أَلَيَْْ اللَّهُ بِعَزْيزٍ ذِي انْتِقَامٍ & 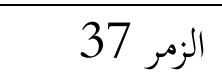 & 6 \\
\hline \multirow[t]{2}{*}{ 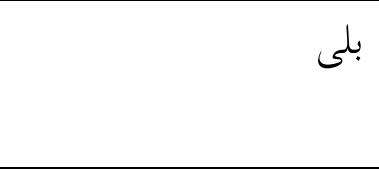 } & ألَيَْْ ذَلِكَ بِقَادِرٍ عَلَى أَنْ يُجِيْيَ & القيامة 40 & 7 \\
\hline & الْمَوْتَى & & \\
\hline \multirow[t]{2}{*}{ اللهم حسبي حسابا يسيرا } & ثخم إنا إلينا إيابهم تثم إن علينا & الغاشية & 8 \\
\hline & حسابهم & & \\
\hline
\end{tabular}

Tabel III menunjukkan bagaimana pembaca atau pendengar teks Alquran merespon pertanyaan-pertanyaan yang ada dalam Alquran. Tentunya jawaban-jawaban tersebut tidak sekedar jawaban ataupun memiliki makna sesingkat jawaban tersebut, jawaban-jawaban tersebut menjadi bagian dari dialog yang terjadi antara teks dan pembacanya, antara internalitas Alquran dan dimensi-dimensi eksternalitas Alquran. Oleh karena itu, sebenarnya kita masih diberi peluang yang sangat luas untuk merespon apa yang ada di dalam Alquran, kita juga selalu diberi pelajaran dari Alquran. Semua itu terjadi tanpa harus melalui kerumitan diskursus penafsiran Alquran. Tentunya disini tidak bermaksud untuk merendahkan kedudukan tafsir dalam studi Alquran tetapi yang perlu digarisbawahi bahwa tradisi pemahaman Alquran berkembang sedemikian rupa dari yang paling sederhana sampai yang paling rumit. Tradisi pemahaman sederhana di antaranya adalah melalui respon-respon atau dialog- 
dialog sederhana antara pembaca dengan teks, pembacaaan Alquran adalah pemahaman atas Alquran.

Perlu digarisbawahi juga bahwa tabel III didasarkan atas hadits-hadits dengan berbagai catatan kualitasnya sebagaimana terdapat dalam tafsir alThabārī. Selain al-Thabārī, ada beberapa intelektual Muslim yang memberi pandangan atas persoalan di atas, namun pada umumnya difokuskan pada ayat terakhir dari surat al-Thin. Oleh karena itu, dari sisi pewacanaan yang ada, persoalan ini tidak mendapat perhatian serius di kalanngan pengkaji Alquran. Mereka cenderung menelaah Alquran dari sisi pemahaman dan penfsiran sebagaimana terus bergulir sampai hari ini. Bibit-bibit upaya mendialogkan Alquran dalam bentuk respon-respon pembaca secara spontan terhadap teks dalam narasi-narasi singkat nampaknya layu sebelum berkembang. Padahal, jika kita mau jujur, pola gagasan mendialogkan Alquran dalam berbagai maknamakna kemanusian yang muncul dari para sahabat, sebagaimana dihadirkan oleh al-Thabārī dalam Jämi al-Bayān, menunjukkan keasalian (authenticity) tafsir sekaligus menunjukkan pola-pola mendialogkan Alquran dalam ruang dan dimensi eksternalitas atau dimensi kemanusiaan Alquran.

\section{Yāsīn Fadīlah}

Dengan kesadaran atas posisi keagungan Alquran di satu sisi dan fakta sejarah bagaimana intelektual Muslim mengeksplorasi makna-makna dan visivisi Alquran, ada satu titik kecil dalam khazanah bagaimana Alquran diperbincangkan yaitu Yāsīn Fadīlah. Sejauh eksplorasi pustaka yang telah penulis lakukan, tidak ada sejarah atau rumusan tentang Yāsīn Fadīlah. Yang ada adalah sebuah buku (kitab) tipis yang diberi judul Yāsīn Fadīlah (يس فضيلة) oleh karena itu Yāsīn Fadīlah dapat dipahami sebagai sebuah teks yang terdiri penggalan Alquran berupa suratYāsīn yang di sebagian ayatnya diselingi dengan kalimat-kalimat doa. Pada versi yang lain, Yāsīn Fadīlah lebih dipahami seagai sebuah aktifitas pembacaan surat Yāsīn yang diselingi dengan pembacaan doadoa tertentu di beberapa ayat yang dianggap sesuai. ${ }^{33}$ Lepas dari teks atau aktifitas, Yāsīn Fadīlah adalah fakta, fakta masyarakat di satu sisi dan fakta bentuk penfasiran atau pemahaman terhadap bagian dari Alquran, di sisi lain.

Fakta-fakta Yāsīn Fadīlah tidak bisa dipungkiri atau diabaikan keberadaanya. Pada saat yang sama, sebagian masyarakat tidak mengenal Yāsīn Fadīlah baik sebagai teks maupun berbagai tradisi yang menyerrtainya. Sebagian masyarakat yang lain berpendapat bahwa fenomena Yāsīn Fadīlah sebagai sesuatu yang mengada-ada, sehingga dianggap tidak perlu ada, dan bahkan

\footnotetext{
${ }^{33}$ Penjelasan lengkap dapat dibaca dalam Aulia no. 03 Tahun XXXIV, Maret 2012.
} 
dianggap menyimpang dari mainstream pemahaman terhadap Alquran. Mereka menempatkan Yāsīn Fadīlah berikut tradisi yang melingkupinya sebagai suatu keliru, menyimpang atau bid'ah yang harus dihentikan. ${ }^{34}$

Dengan latar tersebut, merumuskan pemahaman tentang apa yang dimaksud dengan posisi dan eksistensi Yāsīn Fadīlah dalam perbincangan studi tafsir dan atau studi Alquran dan tawaran konsepsinya sulit ditemukan. Satusatunya kemungkinan pemahaman atas Yāsin Fadīlah adalah dalam konteks mendialogkan Alquran untuk kepentingan atau tujuan tertentu. Dengan demikian, mengetahui arti yang pas dalam memahami Yāsīn Fadīlah dan metode-metode yang diperlukan untuk merumuskan pemahaman tersebut adalah sesuatu yang urgen. Dengan upaya pemahaman berikut metode yang digunakannya, telaah utuh tentang Yāsīn Fadīlah dapat memberi manfaat banyak kepada masyarakat khususnya manfaat pengetahuan yang objektif tentang Yāsinn Fadīlah karena pengetahuan yang objektif tidak akan melahirkan sikap antipati atau sebaliknya sikap yang membabi buta terhadap suatu masalah atau hal tertentu.

Penulis merasa kesulitan untuk melacak asal usul Yāsinn Fadīlah karena minimnya referensi yang penulis temukan. Referensi yang ada justru tentang fadilah surat Yasin atau keutamaan surat Yasin. ${ }^{35}$ Penjelasan tentag keutamaan surat yasin ini bersumber dari hadits-hadits nabi, lepas dari kualitas hadits yang ada, yang dikumpulkan kemudian dijadikan buku, sebagaimana disebutkan di atas. Di sisi lain, dari sisi tata bahasa kalimat Yãsin Fadìlah itu sendiri nampaknya juga rancu karena kata Yäsin kesannya dianggap sebagai bentuk umum (nakirah) sehingga sifatnya Fadilah juga bentuk umum (nakirah). Padahal, semestinya yang benar adalah Sürat Yäsìn al-Fadhilah. Yang jelas, kataYäsin dipahami sebagai susuan huruf-huruf hijai yang tidak memiliki makna spesifik namun memiliki magza yang agung ( عظيما مغزى ) bagi manusia.

Lepas dari persoalan tersebut, sejauh yang penulis temukan, konsep awal Yāsīn Fadīlahterdapat dalam kitab Syams al-Ma'arifi al-Kubrāyang disusun oleh Muhy al-Dīn Ahmad bin Alī al-Būnī (w. 622 H./1225 M) dalam judul سورة دعرة

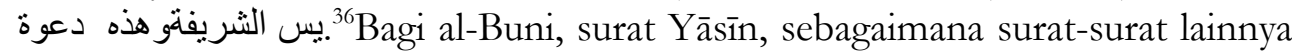

${ }^{34}$ Tanggapan negatif terhadap Yāsīn Fadīlah justru lahir dari karya Mahrus Ali yanng menjelaskan panjang lebar tentang kekeliruan sebagian masyarakat Muslim di Indonesia yang melakukan tradisi pembacaan Yāsīn Fadīlah. Ia menulis Yasin Fadilab: Qur'an Kyai Abli Bid'ah. Lepas dari argumen-argumen yang dibangun oleh pengarangnya, buku ini lebih terkasan sebagai ajang profokasi terhadap tradisi pembacaan Yāsīn Fadīlah yang dilakukan oleh masyarakat yang kebetulan secara mayoritas berafiliasi dengan organisasi Nabdatul Ulama (NU).LihatMahrus Ali, Yasin Fadilab: Qur'an Kyai Abli Bid'ah, (Surabaya : Laa Tasyuk Press, 2006).

${ }^{35}$ Salah satunya adalah karya Muhib al-Din Abd al-Subkhan Wa'idh, Fadha'il Surat Yasin fi Mizan al-Naqd, (Bairut: Muassasah al-Rayyan, 2001).

${ }^{36} \mathrm{Ahmad}$ bin Alī al-Būnī ,Syams al-Ma'ärif al-Kubrā, (tp. tt. th), hlm. 252-263. 
dalam Alquran sebagai bagian proses komunikasi dan dialog manusia dengan Tuhannaya. Manusia melantunkan firman-firman Allah, khususnya dalam surat Yāsin yang diselingi atau ditambahi ungkapan-ungkapan doa dalam beberapa ayatnya dengan bahasa-bahasa yang indah (badī) untuk satu tujuan yakni mengagungkan Tuhan dan meminta pertolongan kepada-Nya, karena hanya Allah-lah zat yang layak untuk diminta. Pola dan proses doa yang disusun oleh al-Būnī ini kemudian banyak mendapat tantangan di kalangan intelektual Muslil lainnya. Ada pendapat yang menyatakan bahwa karya al-Būnī ini termasuk salah satu karya intelektual yang mengandung unsur-unsur mistik dan olkutisme. Itulah Islam popular yang berkembang pada abad ke-12, ada proses integrasi antara tradisi sufisme, tradisi lokal Afrika dan respon ulama atas gerakan mainstream yang berkembang pada waktu itu. ${ }^{37}$ Oleh karena itu, secara sederhana, dan lepas dari adanya pendapat sebagian umat Islam kontemporer seperti komunitas Salafi dan Wahabi yang mempertanyakan status dan eksistensi kitab tersebut baik dari ranah teologis, maupun syari'ah. Dalam pola biner (bukan linier sebagaimana struktur awal teks), doa surat Yäsin al-Syarífah tersebut ada pada tabel IV berikut ini.

\section{Tabel IV}

Yāsīn al-Syarìłah (Yasin Fadilah) versi Kitab Syams al-Ma’arif al-Kubra

\begin{tabular}{|c|c|c|}
\hline أنت تقول بعد قراءها & أيات من سورة يس التى تقرأ & رقم \\
\hline يس & يس & 1 \\
\hline سبحان المنفس عن كل مديون سبحان المخلص & والقرأن الحكيم الى قوله من رب & 2 \\
\hline 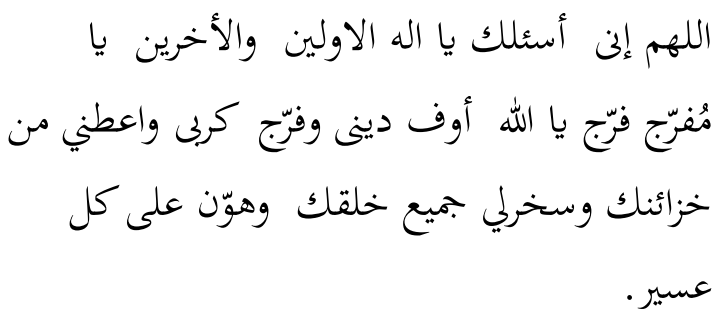 & 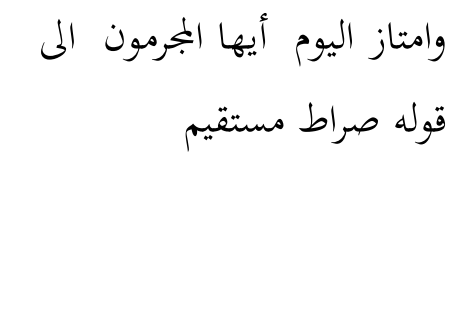 & 3 \\
\hline الصلاة على النبي & ولقد اضل منكم جبلا كثيرا الى & 4 \\
\hline
\end{tabular}

${ }^{37} \mathrm{Hal}$ itu sebagaimana, salah satunya, dipahami oleh Pierre Lory, La magies des letteres dans le "sams al- ma'arif" d' al-Buni" , Bulletin d'etudes orientales, T. 39/40, (19871988). 


\section{قوله لا يرجعون}

5 ومن نعمره ننكسه في الخلق اللهم انى أسئلك يا اله الأولين والأخرين أسئك

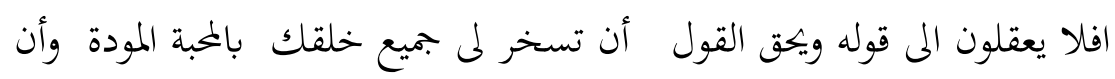

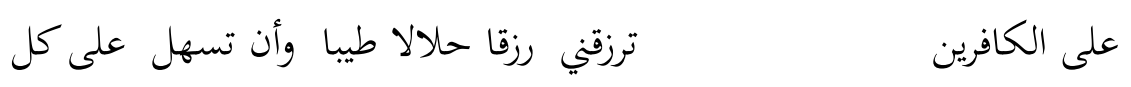
عسير وأن تجعل العسير علي يسيرا.

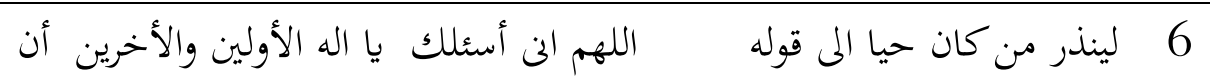

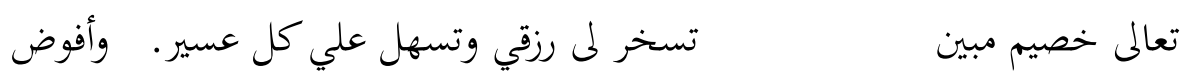

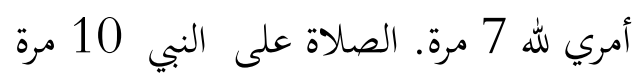

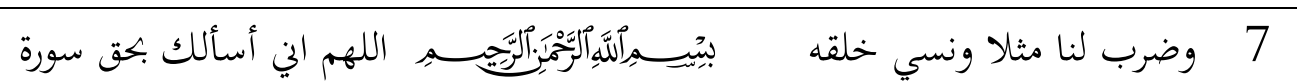

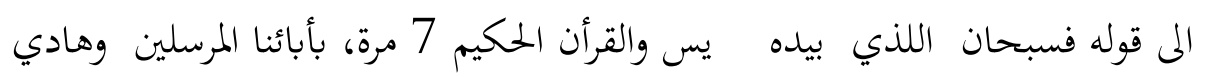

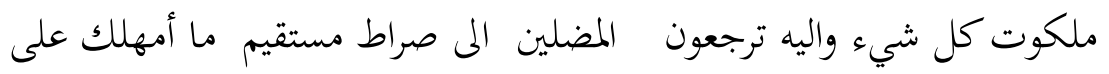

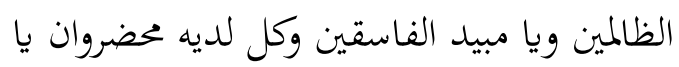
من يهي الموتى ويكتب ما قدموا وأثارهم وكل

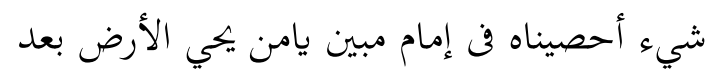
موتا ويخرج منه حبا فمنه يأكلون يامن جعل فيهاء جنات من نخيل وأعناب وفجرها فيها من العيون الى قوله افلا يشكرون * يا من يسبح له كل لسان وفجرهان

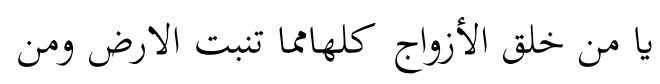

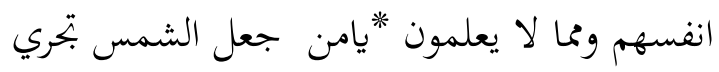

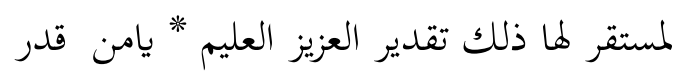

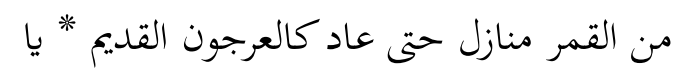

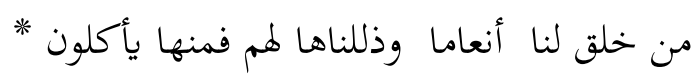
يامن خلق الإنسان من نطفة فاذا هو خصيم

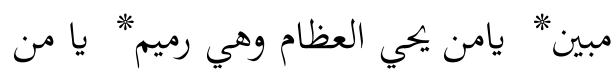




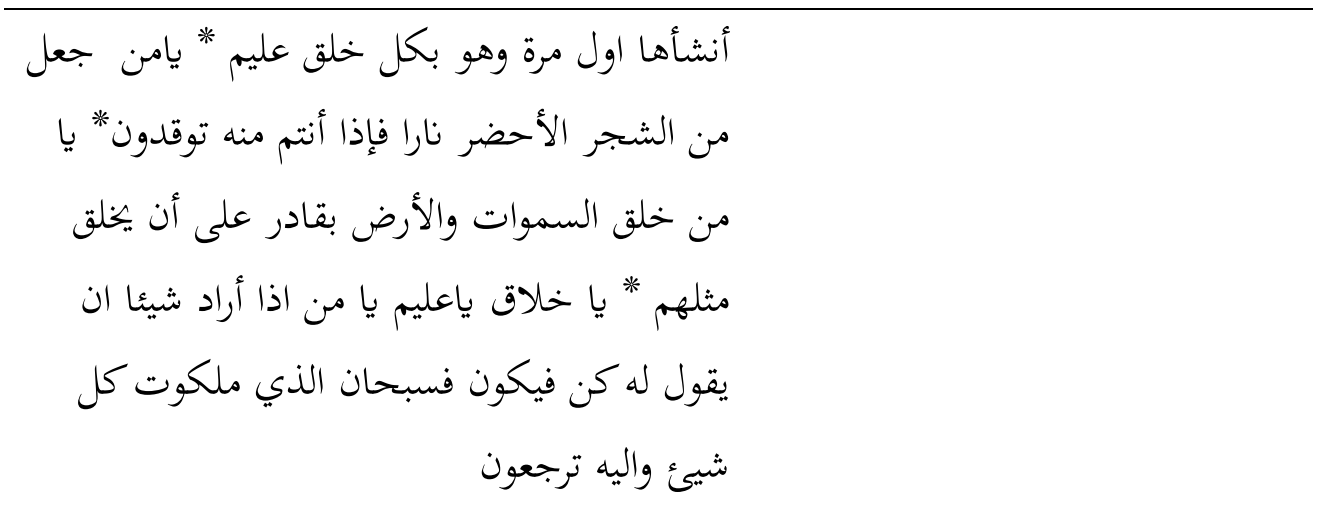

Sebagai bahan perbandingan, di tabel $\mathrm{V}$ berikut ini teks Yäsin alSyari’fahsebagaimana terdapat dalam beberapa buku Yäsin al-Syari’fah versi cetak.

Tabel V

Yasin Fadilah Versi Buku yang Beredar di Indonesia

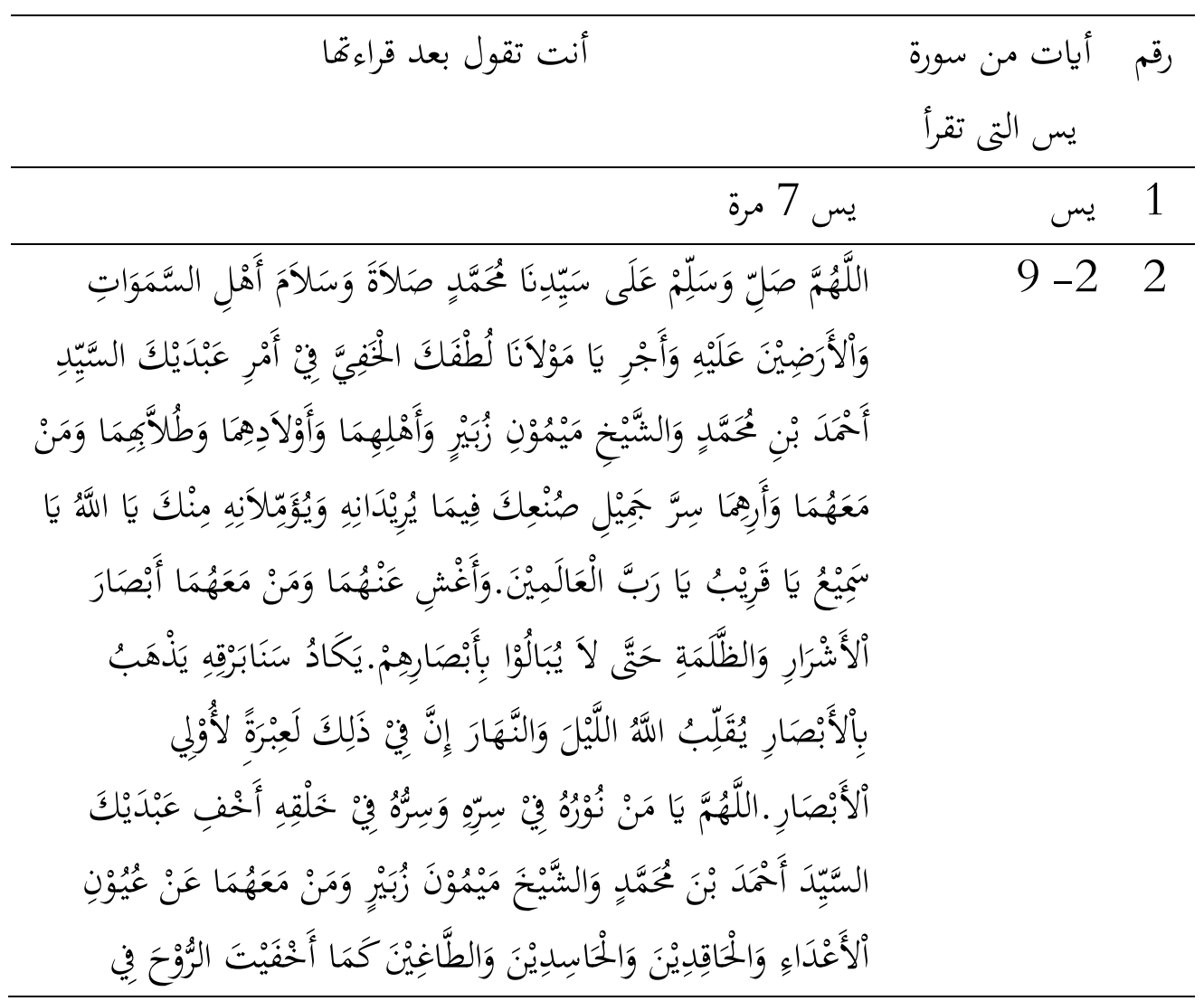




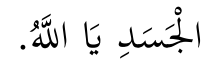

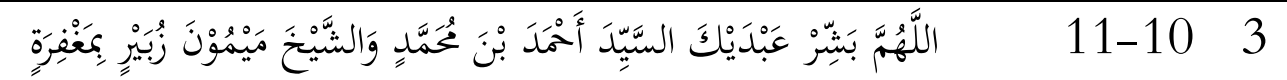

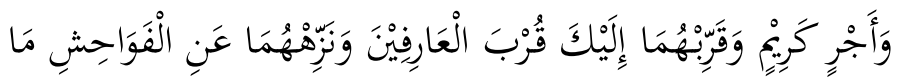

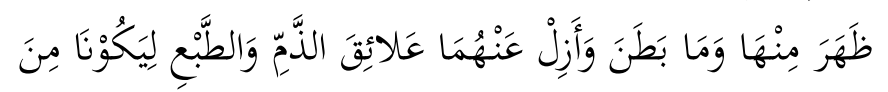

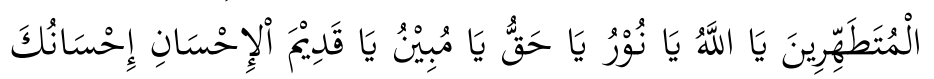

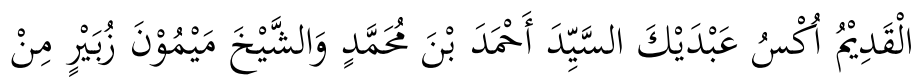

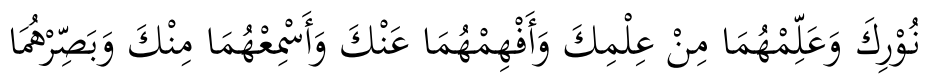

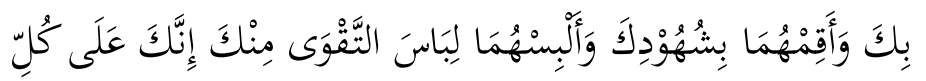

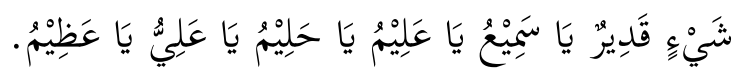

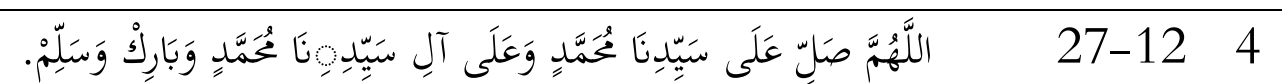

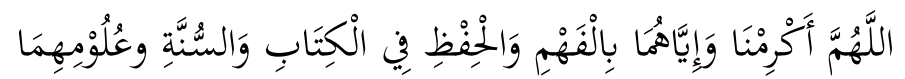

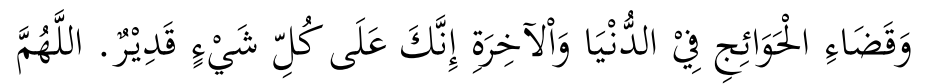

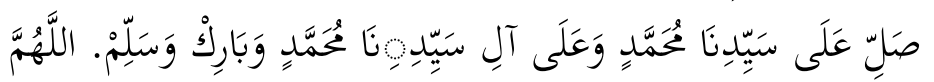

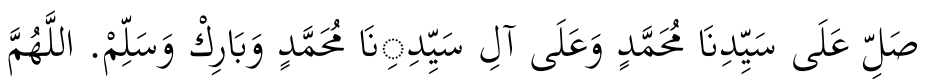

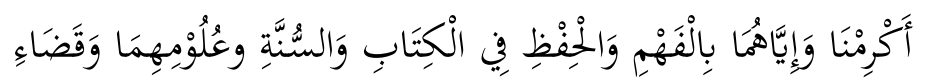

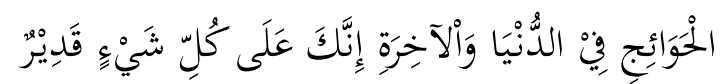

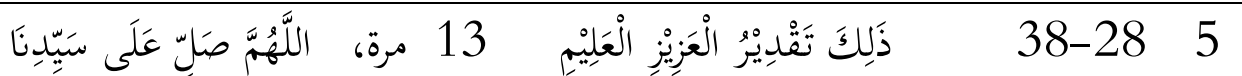

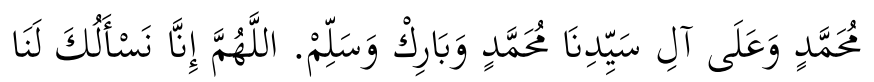

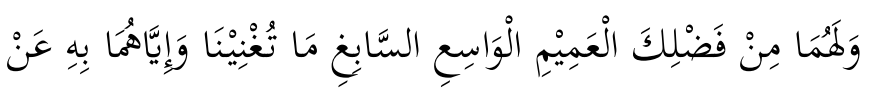

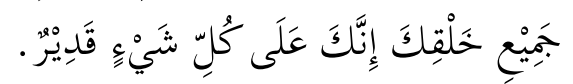

6

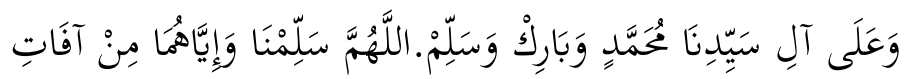

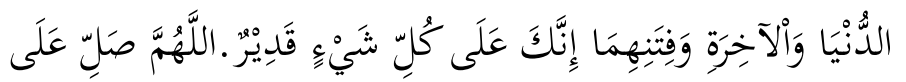

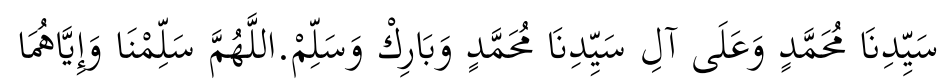




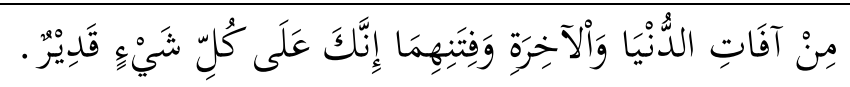

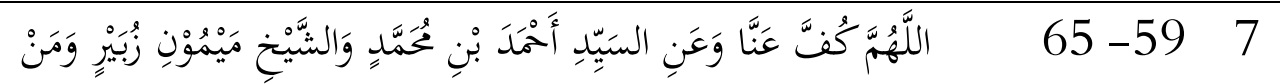

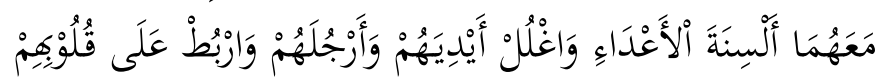

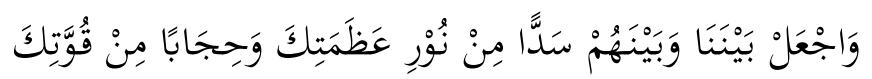

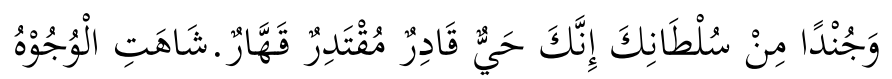

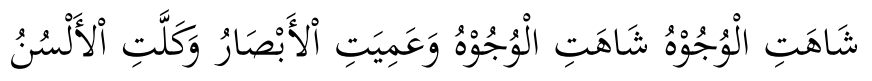

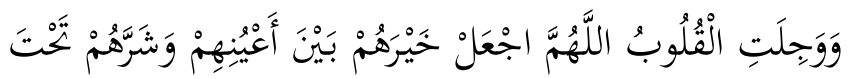

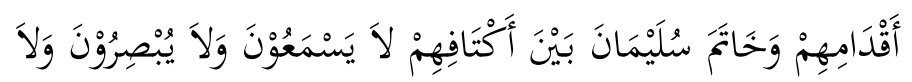

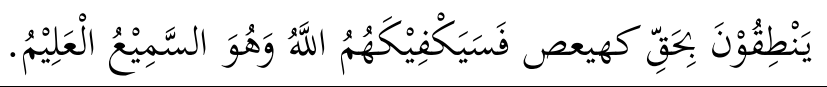

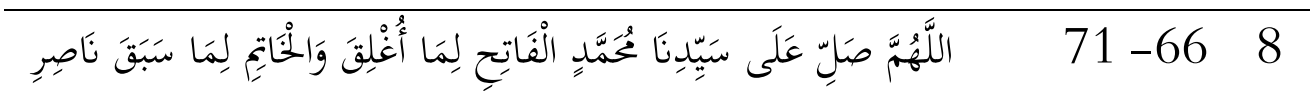

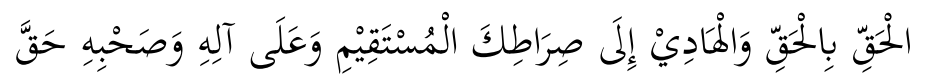

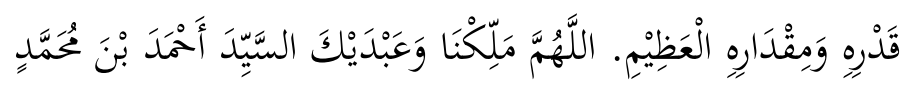

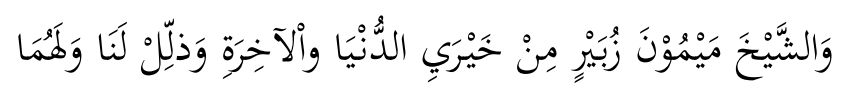

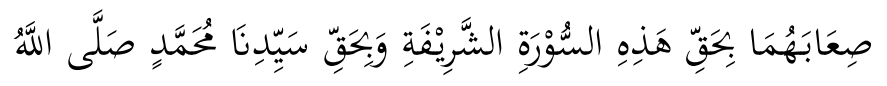

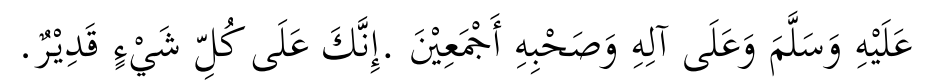

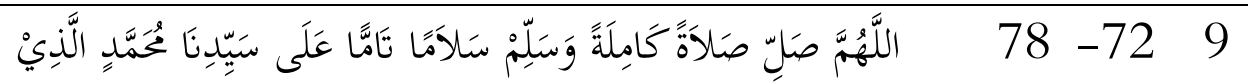

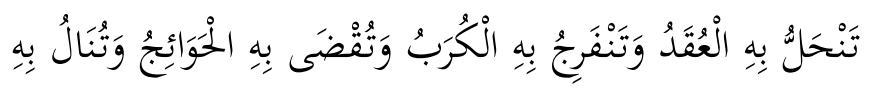

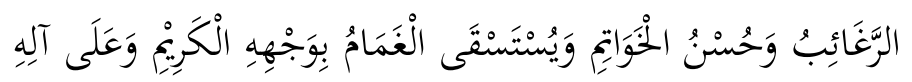

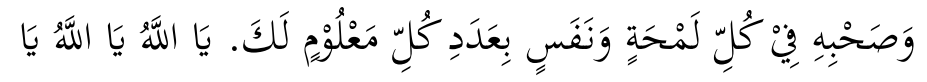

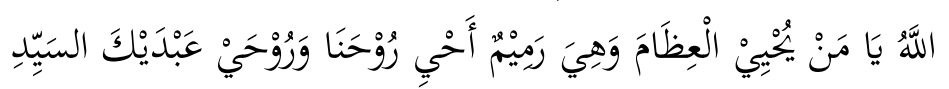

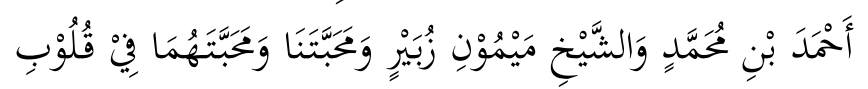




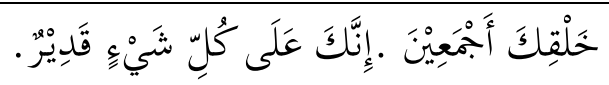

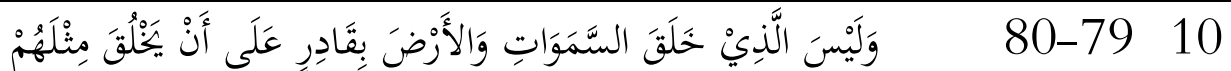

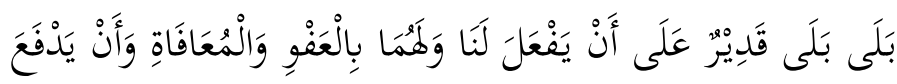

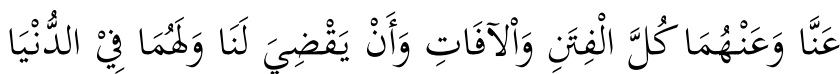

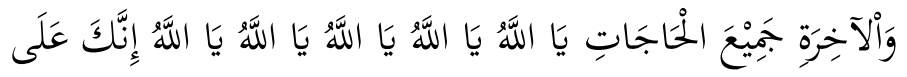

$$
\text { كُلِّن شَيٌِْ قَدِيْر. }
$$

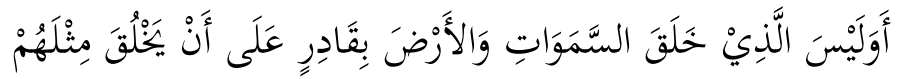

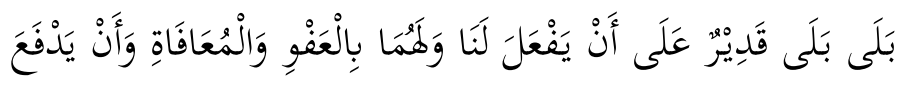

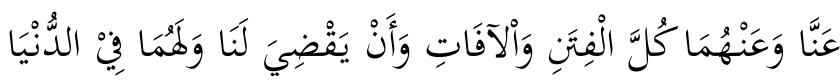

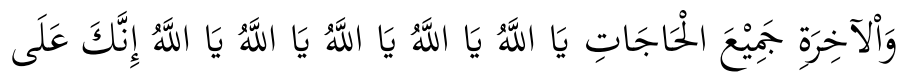

$$
\text { كُلِّن شَيٌِْ قَدِيْر. }
$$

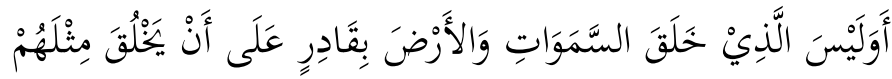

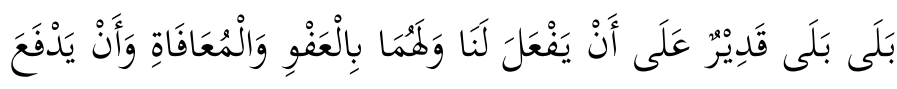

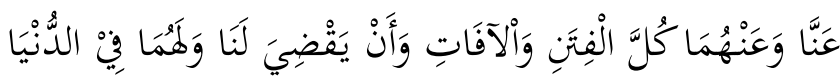

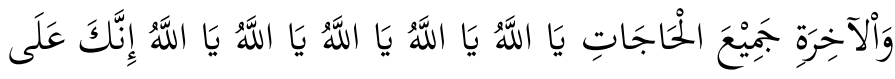

$$
\text { كُلِّل شَيٌِْ قَدِيْرِ. }
$$

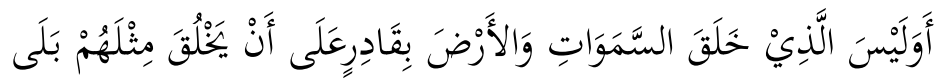

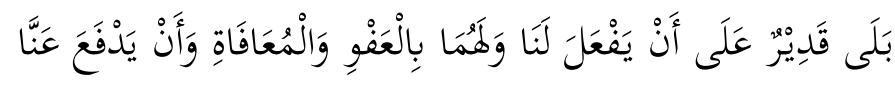

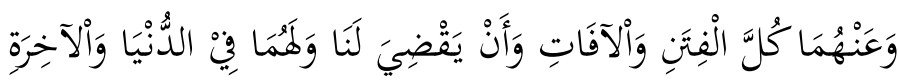

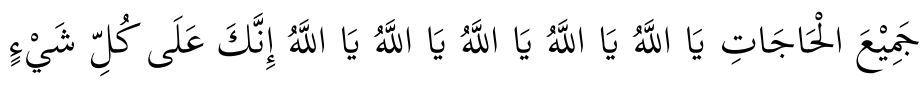
قََدِيْر.

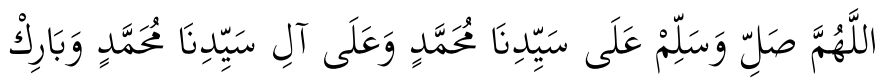




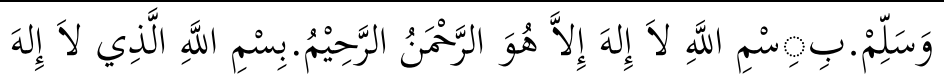

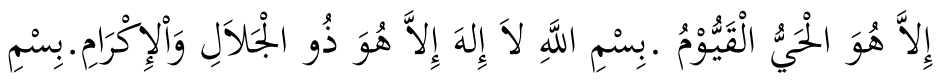

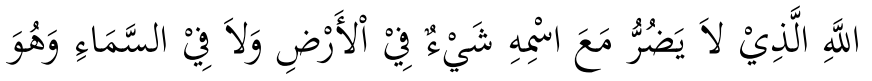

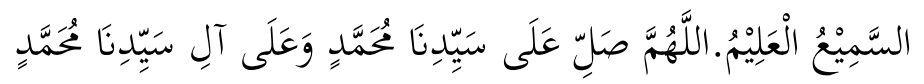

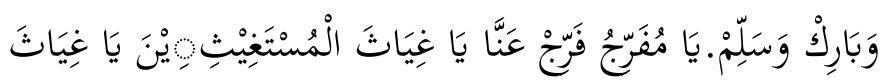

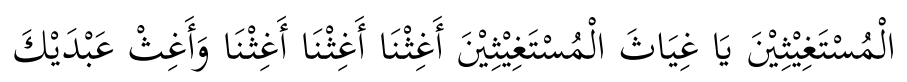

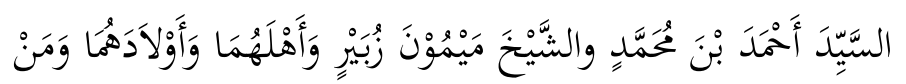

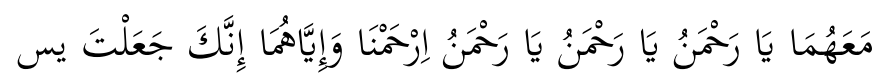

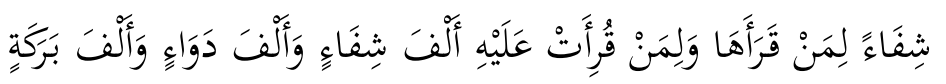

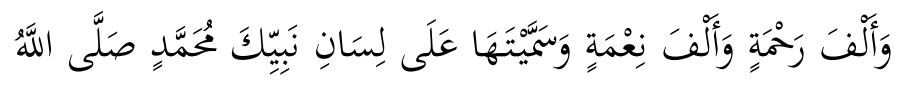

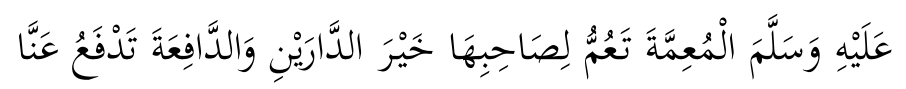

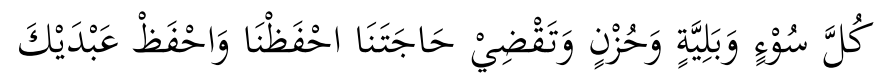

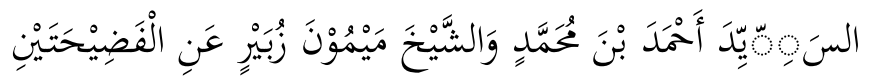

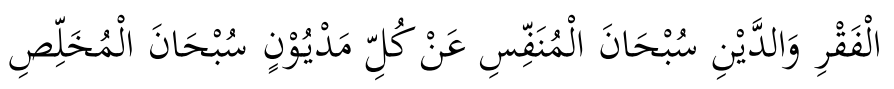

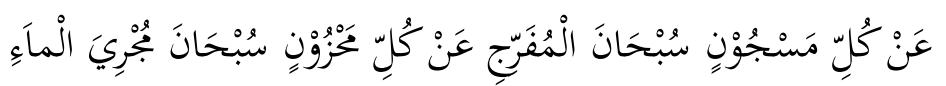

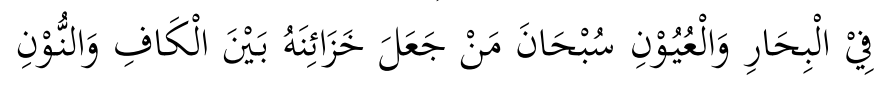

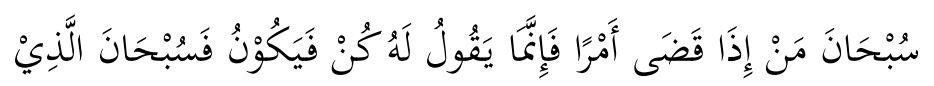

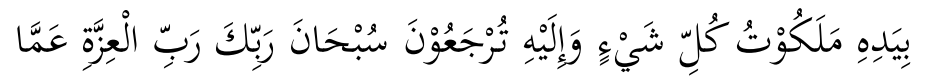

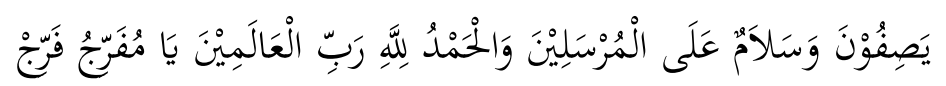

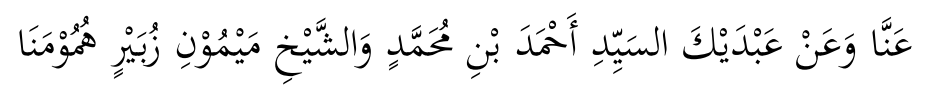

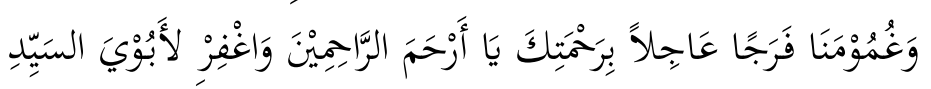

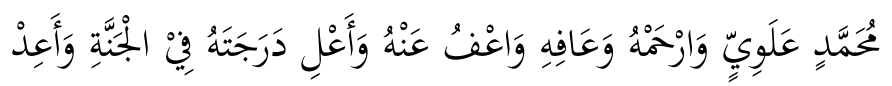

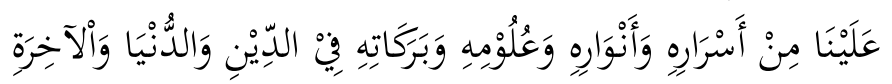




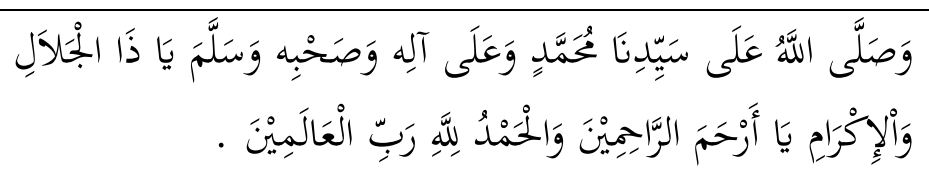

Lepas dari perbedaan yang ada baik di dalam Yasin Fadilah maupun di dalam bab Hādribi Da'wah li Sürat Yäsìn al-Syarifah, keduanya menyajikan teks Alquran yang diselingi dengan kalimat-kalimat puitis berupa doa atau permintaan kepada Allah swt. Artinya, disini seorang pembaca Alquran, khususnya pembaca surat Yāsīn, secara langsung mendialogkan makna-makna yang terkandung dalam surat Yäsinuntuk kemudian diberi tambahan maknamakna yang konkrit dalam konteks keinginan pembacanya. Oleh karena itu, ada kesan mencampuradukan antara Alquran dengan non Alquran. Padahal, fakta sesungguhnya adalah bagaimana pembaca mendialogkan Alquran sesuai keinginan-keinginan pembacanya yang lebih spesifik dengan terus memuji Tuhannya dengan bahasa yang indah dan memohon kepada Tuhannya agar apa yang diinginkan dapat terrealisasi.

\section{Simpulan}

Kata, āminn, aktifitas sujud tilāwah, kalimat-kalimat taqrìryah, dan Yāsīn Fadīlah adalah fenomena historis keagamaan dalam Islam yang sangat dekat keterkaitannya dengan wacana Alquran. Namun demikian, fenomena-fenomena di atas belum dirumuskan secara konseptual baik oleh ulüm al-tafsir maupun ulüm Alquran.Wacana yang ada selama ini hanya disinggung dalam konteks etika pembacaan Alquran dalam kaitannya dengan ibadah-ibadah ritual seperti shalat ataupun etika pembacaan Alquran itu sendiri. Fakta tersebut dapat dirumuskan secara ilmiah dengan menggunakan paradigma dialog internalitas dan eksternalitas Alquran. Dengan latar teoretik tersebut, fenomena kata ämin, aktifitas sujud tilawwah, kalimat-kalimat taqrïryah, dan Yāsīn Fadīlah merupakan bentuk mendialogkan Alquran dalam dimensi eksternalitas Alquran sehingga Alquran menjadi selalu hidup di tengah pembaca, pendengar, dan umatnnya secara umum. Namun demikian proses mendialogkan Alquran yang tumbuh dan berkembang sejak era kenabian bahkan dapat dikatakan sampai sekarang tersebut hanya berkait dengan dimensi-dimensi dan dalam bentuk dialog vertikal antara manusia dengan Tuhannya atau dalam dimensi teologis semata. Oleh karena itu dapat dapat dikatakan bahwa proses mendialoggkan Alquran di atas sebagai bentuk perwujudan living Qur'an era klasik. Setelah itu, tradisi ini menjadi redup karena nalar agama dan pemahaman Alquran jatuh pada nalar orthodoksinya. Artinya, apa yang awalnya dibangun dan dirumuskan sebagai sesuatu yang hidup kemudian berangsung-angsur menjadi statis dan mandeg bahkanmenjadi persoalan ibadah semata. Namun demikian, berangkat dari 
fenomena di atas, peluang untuk mendialogkan Alquran dalam konteks dan dimensi eksternalitasnya masih terbuka lebar tinggal siapa yang mau memulai, dan tentu dengan syarat ada keberanian, kemauan, dan niat yang suci. Selamat mencoba.

\section{Bibliography}

Ali, Mahrus. Yasin Fadilab: Qur'an Kyai Abli Bid'ah. Surabaya: Laa Tasyukki Press, 2006.

Arif, Mahmud. "Aspek Dialogis Alquran dalam Pendidikan: Arti Penting Pembacaan Pedagogis dan Produktif", Jurnal al-Tabrir, Vol. 11, No. 2 (2011).

Attwater, Ronald. The catholic Encyclopedia Dictionary, London: Cassel company, 1949.

al-Bukhari, Abi Abdillah Ismail,Sabih al-Bukhari, Bairut: Dar al-Fikr, 1981.

al-Būnī, Ahmad bin Alī. Syams al-Ma'arifi al-Kubrä, tp. tt. Th.

Damrah, Ma'en Mahmoud Otsman. al-Khiwar fi Alquran al-Karim , (Nablus: alJami'ah al-Najakh al-Wathaniyyah, 2005.

Fadhlullah, Sayyid Mohammad Husain . al-Khiwar fi Alquran : Qawa'idubu, Asalibubu, wa Mu'tiyatubu Bairut: Dar al-Malak, 2007.

al-Ghazālī, Abū Hāmid. Ikehyā Ulüm al-Dìn, juz I. Bairut: Dar al-Fikr, t. th.

al-Laham,Salih bin Abdullah. Sujūd al-Tiläwah wa Ahkämubu, Riyadh: Dar Ibn al-Jauzi, $1429 \mathrm{H}$.

Kementerian Pendidikan dan Kebudayaan RI, Kamus Besar Bahasa Indonesia, Jakarta : Balai Pustaka, 2001.

Lory, Pierre. "La magies des letteres dans le "sams al- ma'arif" d' al-Buni", Bulletin d'etudes orientales, T. 39/40, (1987-1988).

Mir,Mustansir. "Dialogue in the Qur'an", Religion and Language. Vol. 24, No. 1, (1992).

Muallif, Muhammad Zain. Menyingkap Rahasia dan Keutamaan Yasin Fadilah, Surabaya: al-IKhlas, 1999.

al-Nawawi, Yahya bin Syaraf. al-Tibyān fi Adāb Hamalat Alquran, Bairut: Dar alNafais, 1984.

Neuwirth, Angelika. " Qur'an and History: A Disputed Relationship Some reflection on Qur'anic History and History in the Qur'an" Qur'anic Studies, vol. 5, no. 1 (2003). 
184 | AL QUDS : Jurnal Studi Alquran dan Hadis vol. 3, no 2, 2019

al-Suyuthi, Jalal al-Din. al-Itqan fi Ulum Alquran, Bairut: Dar al-Fikr, t. th.

As-Shiddiqie, Hasbi, Tafsir dan Ilmu Tafsir, Jakarta: Bulan Bintang, 1988.

al-Thabārī, Abū Ja'far Muhammad bin Jarīr . Jāmi al-Bayān fì Tafsìr Alquran, juz 28-30, Bairut: Dar al-Ma'rifat, 1972.

Taimiyyah, Taqi al-Din Ahmad Ibn . Sujūd al-Tilāwah: Ma'ān̄̄hi wa Abkāmihi, Bairut: Dar Ibn Hazm, 2011.

Tottoli, Roberto. "Muslim Attitudes Toward Prostration (Sujūd) I: Arabs and Prostrations at the Beginning of Islam and in Qur'an", dalam Studia Islamica, No. 88 (1998).

Wa'idh, Muhib al-Din Abd al-Subkhan. Fadha'il Surat Yasin fi Mizan al-Naqd, Bairut: Muassasah al-Rayyan, 2001. 